\title{
Measurements of biogenic volatile organic compounds at a grazed savannah grassland agricultural landscape in South Africa
}

\author{
Kerneels Jaars $^{1}$, Pieter G. van Zyl ${ }^{1}$, Johan P. Beukes ${ }^{1}$, Heidi Hellén ${ }^{2}$, Ville Vakkari ${ }^{2}$, Micky Josipovic ${ }^{1}$, \\ Andrew D. Venter ${ }^{1}$, Matti Räsänen ${ }^{3}$, Leandra Knoetze ${ }^{1}$, Dirk P. Cilliers ${ }^{1}$, Stefan J. Siebert ${ }^{1}$, Markku Kulmala ${ }^{3}$, \\ Janne Rinne $^{4}$, Alex Guenther ${ }^{5}$, Lauri Laakso ${ }^{1,2}$, and Hannele Hakola ${ }^{2}$ \\ ${ }^{1}$ Unit for Environmental Sciences and Management, North-West University, Potchefstroom, South Africa \\ ${ }^{2}$ Finnish Meteorological Institute, PL 503, 00101 Helsinki, Finland \\ ${ }^{3}$ Department of Physics, University of Helsinki, Helsinki, Finland \\ ${ }^{4}$ Department of Physical Geography and Ecosystem Science Lund University Sölvegatan 12, 22362 Lund, Sweden \\ ${ }^{5}$ Department of Earth System Science, University of California, Irvine, CA, USA
}

Correspondence to: Pieter G. van Zyl (pieter.vanzyl@nwu.ac.za)

Received: 3 June 2016 - Published in Atmos. Chem. Phys. Discuss.: 17 August 2016

Revised: 8 November 2016 - Accepted: 29 November 2016 - Published: 20 December 2016

\begin{abstract}
Biogenic volatile organic compounds (BVOCs) play an important role in the chemistry of the troposphere, especially in the formation of tropospheric ozone $\left(\mathrm{O}_{3}\right)$ and secondary organic aerosols (SOA). Ecosystems produce and emit a large number of BVOCs. It is estimated on a global scale that approximately $90 \%$ of annual BVOC emissions are from terrestrial sources. In this study, measurements of BVOCs were conducted at the Welgegund measurement station (South Africa), which is considered to be a regionally representative background site situated in savannah grasslands. Very few BVOC measurements exist for savannah grasslands and results presented in this study are the most extensive for this type of landscape. Samples were collected twice a week for $2 \mathrm{~h}$ during the daytime and $2 \mathrm{~h}$ during the night-time through two long-term sampling campaigns from February 2011 to February 2012 and from December 2013 to February 2015, respectively. Individual BVOCs were identified and quantified using a thermal desorption instrument, which was connected to a gas chromatograph and a mass selective detector. The annual median concentrations of isoprene, 2-methyl-3-butene-2-ol (MBO), monoterpene and sesquiterpene (SQT) during the first campaign were 14, 7 , 120 and 8 pptv, respectively, and 14, 4, 83 and 4 pptv, respectively, during the second campaign. The sum of the concentrations of the monoterpenes were at least an order of magnitude higher than the concentrations of other BVOC species during both sampling campaigns, with $\alpha$-pinene be-
\end{abstract}

ing the most abundant species. The highest BVOC concentrations were observed during the wet season and elevated soil moisture was associated with increased BVOC concentrations. However, comparisons with measurements conducted at other landscapes in southern Africa and the rest of the world that have more woody vegetation indicated that BVOC concentrations were, in general, significantly lower for savannah grasslands. Furthermore, BVOC concentrations were an order of magnitude lower compared to total aromatic concentrations measured at Welgegund. An analysis of concentrations by wind direction indicated that isoprene concentrations were higher from the western sector that is considered to be a relatively clean regional background region with no large anthropogenic point sources, while wind direction did not indicate any significant differences in the concentrations of the other BVOC species. Statistical analysis indicated that soil moisture had the most significant impact on atmospheric levels of MBO, monoterpene and SQT concentrations, whereas temperature had the greatest influence on isoprene levels. The combined $\mathrm{O}_{3}$ formation potentials of all the BVOCs measured calculated with maximum incremental reactivity (MIR) coefficients during the first and second campaign were 1162 and 1022 pptv, respectively. $\alpha$-Pinene and limonene had the highest reaction rates with $\mathrm{O}_{3}$, whereas isoprene exhibited relatively small contributions to $\mathrm{O}_{3}$ depletion. Limonene, $\alpha$-pinene and terpinolene had the largest contributions to the $\mathrm{OH}$ reactivity of BVOCs measured at 
Welgegund for all of the months during both sampling campaigns.

\section{Introduction}

Ecosystems produce and emit a large number of biogenic volatile organic compounds (BVOCs) that are involved in plant growth and reproduction. These species also act as defensive compounds, e.g. enhancing tolerance to heat and oxidative stress (Sharkey and Yeh, 2001; Loreto and Schnitzler, 2010), preventing the colonization of pathogens after wounding, and deterring insects or recruiting natural enemies of herbivores (Holopainen and Gershenzon, 2010). The $\mathrm{BVOC}$ production rate in an ecosystem depends on several physical (e.g. temperature, precipitation, moisture, solar radiation and carbon dioxide $\left(\mathrm{CO}_{2}\right)$ concentration) and biological (e.g. plant species and the associated emission capacity, phenology, biotic and abiotic stresses, and attraction of pollinators) parameters (Blande et al., 2014; Fuentes et al., 2000; Kesselmeier and Staudt, 1999; Sharkey and Yeh, 2001), with typically 0.2 to $10 \%$ of the carbon uptake during photosynthesis being converted to BVOCs (Kesselmeier et al., 2002). It is estimated that, on a global scale, approximately $90 \%$ of annual BVOC emissions are from vegetation and/or terrestrial sources $\left(\sim 1000 \mathrm{Tg}_{\text {year }}{ }^{-1}\right)$ (Guenther et al., 2012).

BVOCs can contribute significantly to the carbon balance in certain ecosystems (Kesselmeier et al., 2002; Malhi, 2002). BVOC concentrations in ambient air depend on several factors, such as emission rates from vegetation, atmospheric transport and mixing, as well as the chemical composition and oxidative state of the atmosphere, which determine the sink of these species. BVOCs are important in the formation of tropospheric ozone $\left(\mathrm{O}_{3}\right)$ and secondary organic aerosols (SOA). BVOCs in the troposphere react with the major oxidants in the atmosphere, which include tropospheric $\mathrm{O}_{3}$, hydroxyl radicals $(\cdot \mathrm{OH}$; referred to, from here on, as $\mathrm{OH}$ for simplicity) and nitrate radicals $\left(\mathrm{NO}_{3} \cdot\right.$; referred to, from here on, as $\mathrm{NO}_{3}$ for simplicity) (Atkinson and Arey, 2003a). These oxidants strongly affect the concentrations of atmospheric BVOCs (Lelieveld et al., 2008; Di Carlo et al., 2004). BVOCs are also crucial in the formation of the stabilized Criegee intermediate - a carbonyl oxide with two free-radical sites - or its derivative (Mauldin III et al., 2012; Welz et al., 2012), which also contributes to atmospheric oxidation. A complex range of reaction products are formed from atmospheric BVOCs, including less volatile oxygenated compounds that condense to form aerosol particles.

Various studies have indicated the link between BVOCs and the formation of SOA (Vakkari et al., 2015; Andreae and Crutzen, 1997; Ehn et al., 2014), while the influence of BVOCs on the growth of newly formed aerosol particles has also been indicated (Kulmala et al., 2004; Tunved et al., 2006). However, there are many uncertainties associated with the exact chemical reactions and physical processes involved in SOA formation and aerosol particle growth, which largely depends on regional emissions and atmospheric processes (Kulmala et al., 2013; Ehn et al., 2014). Vakkari et al. (2015) indicated the importance of volatile organic compounds (VOCs) for new particle formation and growth in clean background air in South Africa. Therefore, it is essential to understand the sources, transport and transformations of these compounds for air quality management and climate change-related studies, as well as for the modelling of atmospheric chemistry at global, regional and local scales (Laothawornkitkul et al., 2009; Peñuelas and Staudt, 2010; Peñuelas and Llusià, 2003).

Long-term ambient BVOC measurements to establish seasonal cycles have been conducted extensively in several regions, which include boreal forest (Hakola et al., 2009, 2000; Rinne et al., 2000, 2005; Rantala et al., 2015; Räisänen et al., 2009; Eerdekens et al., 2009; Lappalainen et al., 2009), hemiboreal mixed forest (Noe et al., 2012), temperate (Spirig et al., 2005; Stroud et al., 2005; Fuentes et al., 2007; Mielke et al., 2010), Mediterranean (Davison et al., 2009; Harrison et al., 2001) and tropical (Rinne et al., 2002) ecosystems. Shorter campaigns have also been conducted in western and central Africa, which include several different studies in the framework of the African Monsoon Multidisciplinary Analyses (AMMA) (Grant et al., 2008; Saxton et al., 2007) and the EXPeriment for the REgional Sources and Sinks of Oxidants (EXPRESSO) (Serca et al., 2001). Zunckel et al. (2007) and references therein indicated that limited research has been conducted on BVOC emissions in southern Africa, which consisted mainly of short campaigns measuring BVOC emission rates. Considering that BVOC emissions on a global scale are considered to be significantly higher (ca. 10 times) than the emission of anthropogenic VOCs, it is very important that longer-term BVOC measurements are conducted in southern Africa. Furthermore, a large part of the land cover in South Africa consists of a grassland bioregion, as indicated in Fig. 1. Although it is considered that grasslands cover approximately one-quarter of the Earth's land surface, relatively few studies have been conducted on BVOC emissions from grasslands, while there are no long-term BVOC studies reported for these landscapes (Bamberger et al., 2011; Ruuskanen et al., 2011; Wang et al., 2012). Therefore, the aim of this study was to quantify the ambient BVOC concentrations over different seasons at a regional background site in South Africa. In addition, the objective was also to characterize their seasonal patterns, as well as to relate BVOC concentrations measured in southern Africa to levels in other regions in the world. To the best of the authors' knowledge, this is the first record of ambient BVOC concentrations covering a full seasonal cycle in southern Africa and for a grassland bioregion anywhere in the world. 




Figure 1. Map of southern Africa indicating the location of the Welgegund measurement station within the context of the bioregion and large point sources in the industrial hub of South Africa (Mucina and Rutherford, 2006).

\section{Measurement location and methods}

\subsection{Site description}

Measurements were conducted at the Welgegund measurement station $\left(26.57^{\circ} \mathrm{S}, 26.94^{\circ} \mathrm{E} ; 1480 \mathrm{~m}\right.$ a.s.l.) (Welgegund measurement station, 2016), which is located on the property of a commercial maize and cattle farmer approximately $100 \mathrm{~km}$ west of Johannesburg, as indicated in Fig. 1. Welgegund is a regional background station with no pollution sources in close proximity. The distances to the nearest blacktop road and nearest town are approximately 10 and $30 \mathrm{~km}$, respectively. Welgegund is, however, affected by the major anthropogenic source regions in the north-eastern interior of South Africa (as indicated by the major large point sources in Fig. 1), which also include the JohannesburgPretoria conurbation (Tiitta et al., 2014). From Fig. 1, it is also evident that the western sector contains no major anthropogenic point sources and can therefore be considered to be representative of a relatively clean regional background.

Welgegund is geographically located within the South African Highveld, which is characterized by two distinct seasonal periods, i.e. a dry season from May to September that predominantly coincides with winter (June to August), and a wet season during the warmer months from October to April. The dry period is characterized by low relative hu- midity, whereas the wet season is associated with higher relative humidity and frequent rains that predominantly occur in the form of thunderstorms. The mean annual precipitation is approximately $500 \mathrm{~mm}$ with $>80 \%$ of rain events occurring during the wet season. During the sampling period, the coldest temperature recorded in winter at Welgegund was $-5.1{ }^{\circ} \mathrm{C}$ in June 2011 , while the highest temperature recorded in summer was $+35.6^{\circ} \mathrm{C}$ in October 2011. The mean maximum temperature ranges between 16 and $32^{\circ} \mathrm{C}$, while the mean minimum temperature ranges between 0 and $15^{\circ} \mathrm{C}$. Winters are also characterized by frequent and severe frost days (26-37 days per year) (Mucina and Rutherford, 2006).

\subsection{Vegetation}

The Welgegund measurement station is located in a grassland biome (Fig. 1), which covers $28 \%$ of South Africa's land surface (Mucina and Rutherford, 2006). This biome has been significantly transformed, primarily as a result of cultivation, plantation forestry, urbanization and mining (Daemane et al., 2010, and references therein). It has also been severely degraded by erosion and agricultural development. The station is situated on the sandy grasslands within the VaalVet rivers in the Andesite Mountain Bushveld of a savannah biome, which is prominent on nearby ridges. At present, 
only $0.3 \%$ of the Vaal-Vet sandy grassland is statutorily conserved, while the rest is mostly used for grazing and crop production. In Fig. 2, a land cover map within a $60 \mathrm{~km}$ radius of Welgegund is presented, indicating the extent of cultivation in this region. The land cover survey was performed within a region that was estimated to represent the BVOC footprint at Welgegund, which was calculated from typical atmospheric lifetimes (Table 1) of the species measured and the general wind speed(s) (Fig. 3) at Welgegund. The immediate area surrounding Welgegund is grazed by livestock, with the remaining area covered by crop fields (mostly maize and to a lesser degree sunflower). In the demarcated $60 \mathrm{~km}$ radius, a further three vegetation units of the dry Highveld grassland bioregion (grassland biome) and another two of the central Bushveld bioregion (savannah biome) are also present. In addition, alluvial vegetation is found associated with major rivers and inland saline vegetation in scattered salt pans.

The study area comprises a highly variable landscape with scattered hills and sloping, slightly irregular, undulating plains, which are dissected by prominent rocky ridges. Soil in the catchment area is heterogeneous and rocky, varying from sandy to clayey depending on the underlying rock types, such as andesite, chert, dolomite, mudstone, quartzite, sandstone and shale.

Land use within the surrounding area is divided into six major land cover types, i.e. cultivated land, grasslands, mountainous areas, plantations, urban areas and water bodies, as indicated in Fig. 2. Mountainous areas, grasslands and water bodies (riparian areas) comprised many different vegetation units. The other homogenous areas were anthropogenically altered and are no longer representative of the surrounding natural vegetation. The study area is characterized by a grassland-woodland vegetation complex, dominated by various grass and woody species, and recognized by the presence of non-native species in altered environments.

The most dominant woody species of the entire study area include the trees Celtis africana, Searsia pyroides, Vachellia karroo and Ziziphus mucronata, and the thorny shrub Asparagus laricinus. Tree diversity increases where there are patches of deep sand, characterized by Gymnosporia buxifolia and Vachellia erioloba, or in mountainous areas, where Euclea undulata, Grewia flava and Senegallia caffra are more prominent. Woody vegetation occurs sparsely in grasslands and when present is found on isolated ridges, including the small trees Pavetta zeyheri, Vangueria infausta and Zanthoxylum capense. In anthropogenically altered environments, native species decrease and introduced species dominate, such as Eucalyptus camaldulensis, Pinus roxburghiana and Populus canescens in plantations; Gleditsia triacanthos, Pyracantha coccinea and Salix babylonica along rivers and water bodies; and Celtis sinensis, Melia azedarach and Robinia pseudoacacia in the urban footprint.

The most dominant species of the grass sward in the entire study area include Cynodon dactylon, Eragrostis chloromelas, Heteropogon contortus, Setaria sphacelata and Themeda triandra. The dry, western grassland (Vaal-Vet sandy grassland specifically) is characterized by Anthephora pubescens, Cymbopogon caesius, Digitaria argyrograpta, Elionurus muticus and Eragrostis lehmanniana, and the moist Rand Highveld grassland in the south-east by Ctenium concinnum, Digitaria monodactyla, Monocymbium ceresiforme, Panicum natalense and Trachypogon spicatus. The northeastern parts of the study area situated on dolomite are dominated by Brachiaria serrata, Digitaria tricholaenoides, Eragrostis racemosa and Loudetia simplex.

\subsection{Measurement methods}

\subsubsection{BVOC measurements and analysis}

BVOC measurements were conducted for a period of more than 2 years through a 13 month sampling campaign from February 2011 to February 2012 and a 15 month sampling campaign from December 2013 to February 2015. Samples were collected twice a week for $2 \mathrm{~h}$ during the daytime (11:00 to 13:00 local time, $\mathrm{LT})$ and $2 \mathrm{~h}$ during the night-time (23:00 to 01:00 LT) on Tuesdays and Saturdays. Several previous studies have demonstrated that the maximum emissions of isoprene and monoterpene from vegetation occur around midday (Fuentes et al., 2000; Kuhn et al., 2002). Understandably, the chosen sampling schedule, i.e. same days each week and same hours of the day, was prone to some bias. As mentioned by Jaars et al. (2014), considering the distance of the sampling site from the nearest town and logistical limitations during the sampling campaigns, the sampling schedule applied was the most feasible option that enabled the collection of data for more than 2 years. VOCs were sampled at a height of $2 \mathrm{~m}$ above ground level, with a $1.75 \mathrm{~m}$ long inlet. The first $1.25 \mathrm{~m}$ of the inlet was a stainless steel tube (grade 304 or 316) and the second $0.5 \mathrm{~m}$ was Teflon. To prevent the degradation of BVOCs by $\mathrm{O}_{3}$, the stainless steel part of the inlet was heated to $120^{\circ} \mathrm{C}$ using heating cables and thermostats (Thermonic), thereby removing ozone from the sample stream (Hellén et al., 2012a). At regular intervals, the efficiency of this $\mathrm{O}_{3}$ removal was verified with an $\mathrm{O}_{3}$ monitor, which indicated that $\mathrm{O}_{3}$ concentrations decreased from median values $\geq 30$ to $<2$ ppb (Jaars et al., 2014).

VOCs were collected with stainless steel adsorbent tubes $(6.3 \mathrm{~mm} \mathrm{ED} \times 90 \mathrm{~mm}, 5.5 \mathrm{~mm}$ ID) packed with Tenax-TA and Carbotrap-B by using a constant-flow type automated programmable sampler. A detailed description of the sampling procedure is presented by Jaars et al. (2014). In short, the flow rate of the pump was set at between 100 and $110 \mathrm{~mL} \mathrm{~min}^{-1}$ throughout the campaigns and was calibrated each week. Prior to sampling, all adsorbent tubes were tested for leaks and preconditioned with helium for $30 \mathrm{~min}$ at $350^{\circ} \mathrm{C}$ at a flow of $40 \mathrm{~mL} \mathrm{~min}{ }^{-1}$. The adsorbent tubes were removed from the sampler once a week and closed off with Swagelok ${ }^{\circledR}$ caps. Each tube was stored in a container for 




Figure 2. General vegetation map for $60 \mathrm{~km}$ radius of Welgegund measurement station. 
(a)

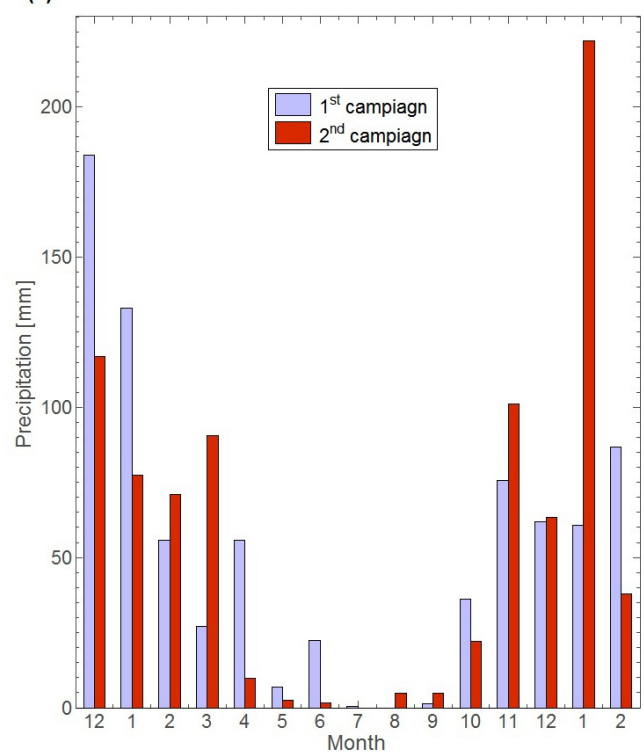

(c)

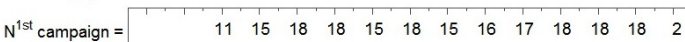

$\mathrm{N}^{2 \text { nd }}$ campaign $=\mid \begin{array}{lllllllllllllll}8 & 11 & 12 & 16 & 2 & 18 & 15 & 7 & 10 & 18 & 14 & 12 & 18 & 17 & 10\end{array}$

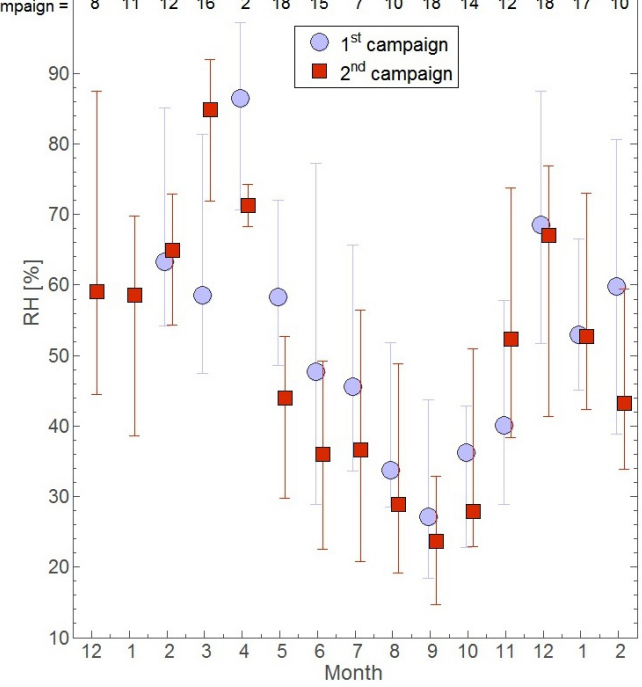

(b)

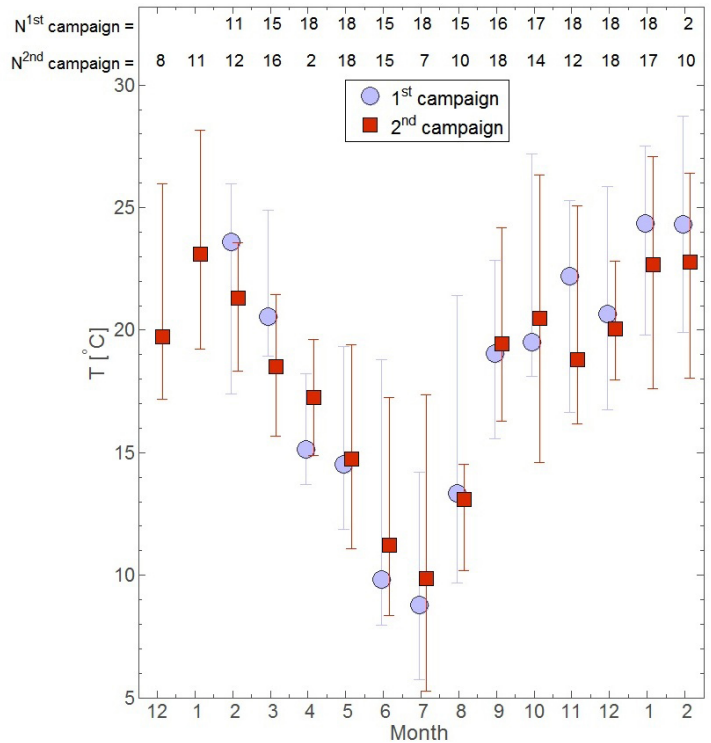

(d)

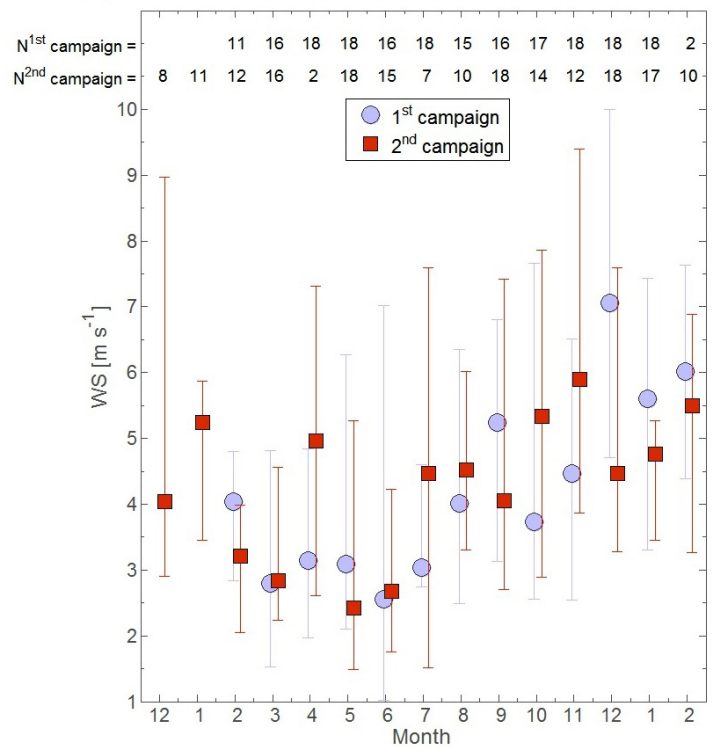

Figure 3.

transport to the laboratory, where the adsorbent tubes were stored in a freezer for 2 to 4 weeks prior to analysis.

Individual BVOCs were identified and quantified using a thermal desorption instrument (Perkin-Elmer TurboMatrixTM 650, Waltham, USA) connected to a gas chromatograph (Perkin-Elmer ${ }^{\circledR}$ Clarus $^{\circledR}$ 600, Waltham, USA) with a DB-5MS $(60 \mathrm{~m}, 0.25 \mathrm{~mm}, 1 \mu \mathrm{m})$ column and a mass selective detector (Perkin-Elmer ${ }^{\circledR}$ Clarus $^{\circledR}$ 600T, Waltham, USA). Samples were analysed using the selected ion mode (SIM). A five-point calibration was performed by using liquid standards in methanol solutions. Standard solutions were injected onto adsorbent tubes that were flushed with helium at a flow of $100 \mathrm{~mL} \mathrm{~min}^{-1}$ for $10 \mathrm{~min}$ in order to remove methanol. BVOCs quantified for the two campaigns included isoprene with a method detection limit (MDL) between 1.2 and 2.4 pptv and 2-methyl-3-butene-2-ol (MBO) with a MDL between 0.9 and $1.4 \mathrm{pptv}$. The monoterpene $(\alpha$-pinene, camphene, $\beta$-pinene, $\Delta^{3}$-carene, limonene, 1,8-cineol, terpinolene, nopinone and bornylacetate) and monoterpenerelated BVOC (p-cymene, 4-allylanisole and 4-acetyl-1methylcyclohexene (AMCH)) MDLs were between 0.6 and $1.6 \mathrm{pptv}$. The term "monoterpene(s)" used in the discussions in subsequent sections in the manuscript refers to both the monoterpene and monoterpene-related BVOCs. The sesquiterpene (SQT) (longicyclene, iso-longifolene, aromadendrene, $\alpha$-humulene and alloaromadendrene) MDLs 


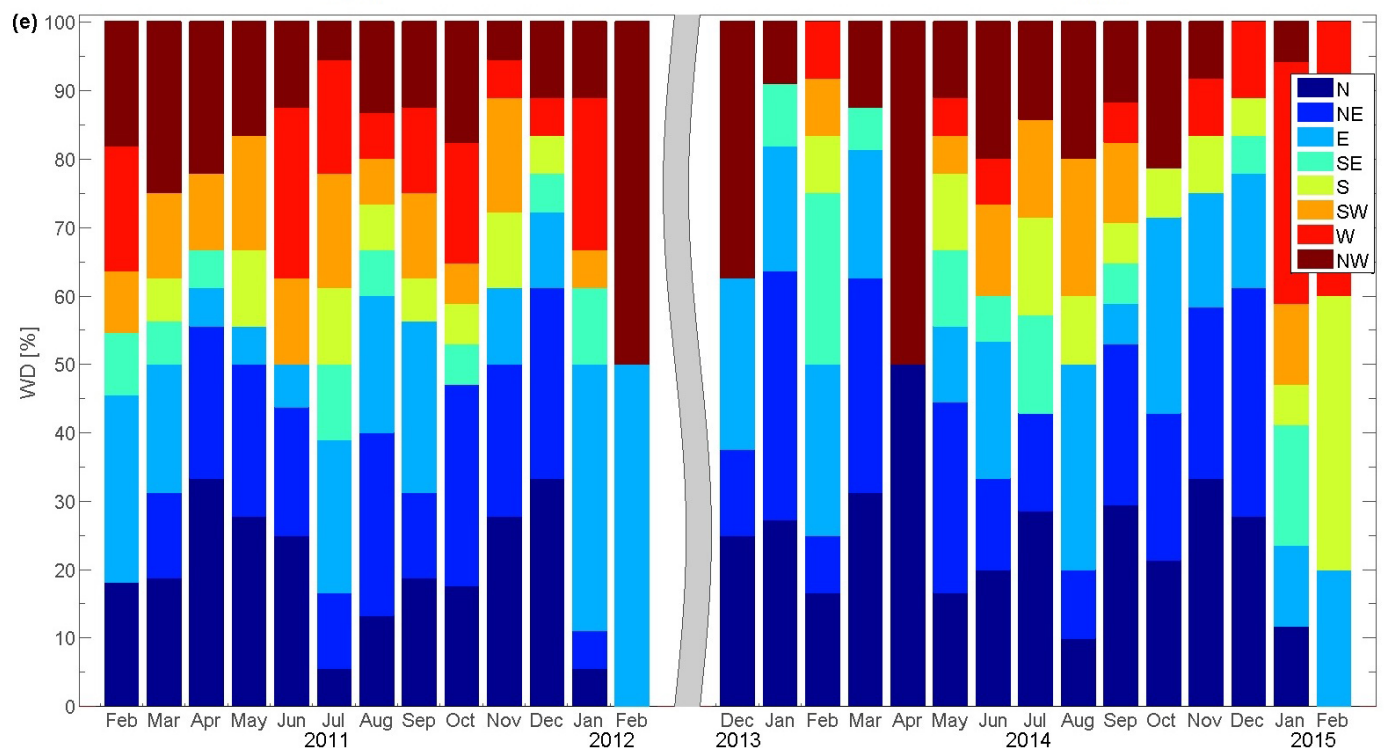

(f)

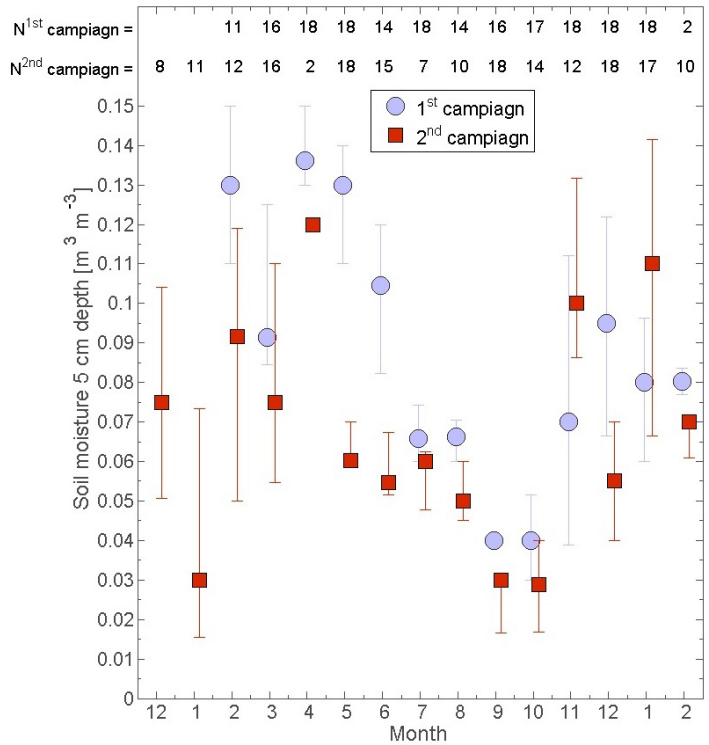

(g)

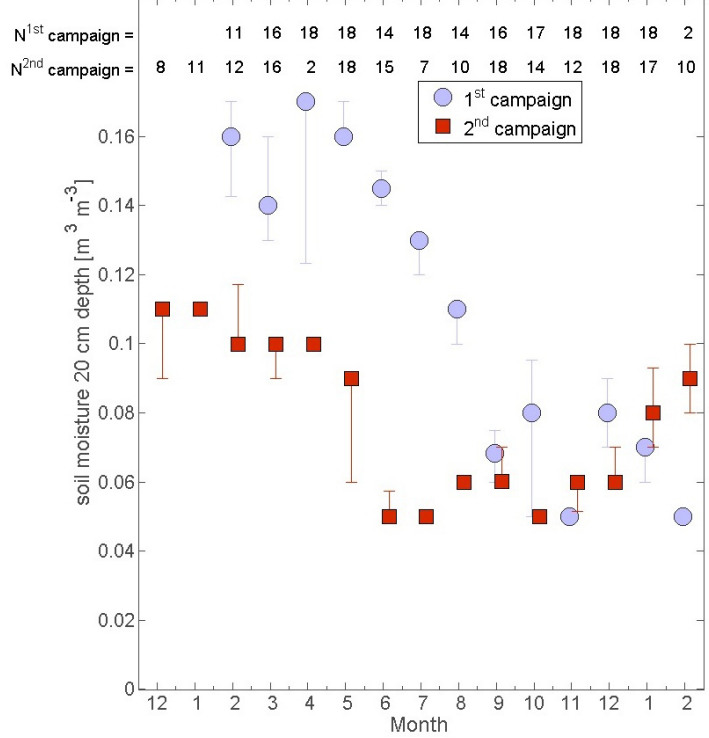

Figure 3. Monthly variation of (a) accumulated precipitation, (b) temperature, (c) relative humidity, (d) wind speed, (e) wind direction, and (f) and (g) soil moisture at 5 and $20 \mathrm{~cm}$ depth, respectively. Error bars indicate upper and lower quartiles.

were $\sim 0.6 \mathrm{pptv}$. Since the analytical system did not separate myrcene and $\beta$-pinene, the determined $\beta$-pinene concentrations were the sum of these two species. VOC concentrations were field and lab blank corrected. When monthly median BVOC concentrations were calculated, sample concentrations below the MDL were replaced with one-half MDL.

\subsubsection{Ancillary measurements}

Ancillary measurements continuously performed at the Welgegund station were used to interpret the measured BVOC concentrations. General meteorological parameters, i.e. temperature $(T)$, relative humidity $(\mathrm{RH})$, wind speed and direc- tion, and precipitation were measured. Soil temperature and moisture at different depths $(5$ and $20 \mathrm{~cm})$ were measured with a PT-100 and Theta probe ML2x (Delta-T), respectively. Additional soil moisture information was obtained with a $100 \mathrm{~cm}$ PR2 soil moisture profile probe (Delta-T). Direct photosynthetic photon flux density (PPFD) between 400 and $700 \mathrm{~nm}$ was measured with a Kipp \& Zonen pyranometer (CMP 3 pyranometer, ISO 9060:1990 Second Class).

Trace gas measurements were performed utilizing a Thermo-Electron $43 \mathrm{~S}$ sulfur dioxide $\left(\mathrm{SO}_{2}\right)$ analyser (Thermo Fisher Scientific Inc., Yokohama-shi, Japan), a Teledyne 200AU nitrogen oxide $\left(\mathrm{NO}_{x}\right)$ analyser (Advanced Pollution 
Instrumentation Inc., San Diego, CA, USA), an Environment SA $41 \mathrm{M} \mathrm{O}_{3}$ analyser (Environment SA, Poissy, France) and a Horiba APMA-360 carbon monoxide (CO) analyser (Horiba, Kyoto, Japan). The net ecosystem exchange (NEE) of $\mathrm{CO}_{2}$ was measured with the eddy covariance method with a Licor 7000 closed path infrared gas analyser and a threedimensional Metek sonic anemometer at a height of $9 \mathrm{~m}$, which is well above the average tree height of $2.5 \mathrm{~m}$ (Räsänen et al., 2016). A more detailed description of additional parameters monitored at Welgegund is given by Beukes et al. (2015).

\subsubsection{Lifetime of BVOCs}

In Table 1, the atmospheric lifetimes $(\tau)$ of BVOCs measured in this study calculated from $\mathrm{OH}$ and $\mathrm{O}_{3}$ reactivity are reported. BVOC lifetimes according to $\mathrm{O}_{3}$ reactivity were calculated with Eq. (1):

$$
\tau=\tau_{\mathrm{O}_{3}}=\frac{1}{k_{\mathrm{O}_{3}},\left[\mathrm{O}_{3}\right]},
$$

where $\left[\mathrm{O}_{3}\right]$ is the annual average $\mathrm{O}_{3}$ concentration (ca. $36 \mathrm{ppbv}$ ) measured during the two campaigns at Welgegund and $k_{\mathrm{O}_{3}}$ the reaction rate constant for the reaction between a specific $\mathrm{BVOC}$ and $\mathrm{O}_{3}$. Since direct $\mathrm{OH}$ reactivity measurements were not available, the average concentration of $\mathrm{OH}$ radicals $([\mathrm{OH}])$ (ca. 0.04 pptv) reported by Ciccioli et al. (2014) was used in the calculations, using Eq. (2):

$$
\tau=\tau_{\mathrm{OH}}=\frac{1}{k_{\mathrm{OH}},[\mathrm{OH}]},
$$

where $k_{\mathrm{OH}}$ is the reaction rate constant for the reaction between a specific BVOC and $\mathrm{OH}$.

\section{Results and discussion}

\subsection{Meteorological conditions during the measurement campaigns}

Local meteorological influences on the measured BVOC concentrations are likely to be more significant than regional impacts of air masses due to the short lifetimes associated with atmospheric BVOCs (Table 1). Therefore, BVOC concentrations were only interpreted in terms of local meteorological patterns and no back trajectory analyses were employed. In Fig. 3, the monthly medians of the meteorological parameters - precipitation, $T$, $\mathrm{RH}$, wind speed and direction, and soil moisture depth $(5$ and $20 \mathrm{~cm})$ - measured at Welgegund during each of the two sampling campaigns are presented. From Fig. 3a and b, the wet season (October to April) associated with warmer months and the dry season (May to September) associated with colder months as discussed in Sect. 2.1 are evident. Rainfall in this region of South Africa is typically characterized by relatively large inter-annual variability (Conradie et al., 2016). The monthly median temperatures for the periods during which samples were collected ranged between 8.8 and $13^{\circ} \mathrm{C}$ in winter and 19.7 and $24.9^{\circ} \mathrm{C}$ in summer (Fig. 3b). During the warmer months, temperatures up to $30^{\circ} \mathrm{C}$ and higher were reached frequently. During the wet season, the monthly median $\mathrm{RH}$ ranged between 30 (with the onset of the wet season) and $80 \%$ (at the end of the wet season), while the RH ranged between 20 and $50 \%$ during the dry season (Fig. 3c). The highest monthly median wind speeds occurred during the warmer months (Fig. 3d) when unstable meteorological conditions are prevalent in the interior of South Africa (Tyson et al., 1996). The seasonal variations of wind direction during the two sampling campaigns (Fig. 3e) indicated that the prevailing wind direction was from the northern to eastern sector, which agrees with the back trajectory analysis performed for the first sampling period at Welgegund by Jaars et al. (2014). Soil moisture measurements mimicked the seasonal precipitation pattern, i.e. higher soil moisture associated with the wet season (Fig. 3f and g). The soil moisture measurements conducted from January to August at a depth of $20 \mathrm{~cm}$ were significantly higher during the first sampling campaign. During December 2010 and January 2011, prior to the first sampling campaign, precipitation (Fig. 3a) was clearly higher than during the second campaign, i.e. December 2013 to January 2014. Subsequently, the soil moisture measured at $20 \mathrm{~cm}$ (Fig. $3 \mathrm{~g}$ ) was clearly higher during the first sampling campaign than during the second campaign from the beginning of the campaign until the middle of the dry season.

Figure 4 presents micrometeorological $\mathrm{CO}_{2}$ flux measurements at Welgegund, which indicate typical changes in the seasonal uptake of $\mathrm{CO}_{2}$ by vegetation. In addition, the PPFD is also indicated with a colour bar. Negative values (downward $\mathrm{CO}_{2}$ flux) indicate the net uptake of $\mathrm{CO}_{2}$ by vegetation, with the gross primary production exceeding the total respiration. Positive values indicate the emission of $\mathrm{CO}_{2}$ by the vegetation. A period of an approximately 0 (small positive) net $\mathrm{CO}_{2}$ flux is observed in the winter months that extend until September, which can be attributed to decreased microbial activity associated with lower temperatures, low rainfall and most of the vegetation losing their leaves. The NEE at full light (maximum downward flux) increases gradually until February in response to the increases of the photochemical efficiency of $\mathrm{CO}_{2}$ assimilation in the vegetation surrounding the site and the solar elevation angle. The daily maximum NEE starts to decrease in March/April when the solar elevation angle declines and soil moisture drops.

\subsection{Contextualizing BVOC concentrations measured at Welgegund}

In Table 2, the median (mean) and inter-quartile range (IQR; 25th to 75th) concentrations, as well as the median (mean) daytime to night-time concentration ratios of the 

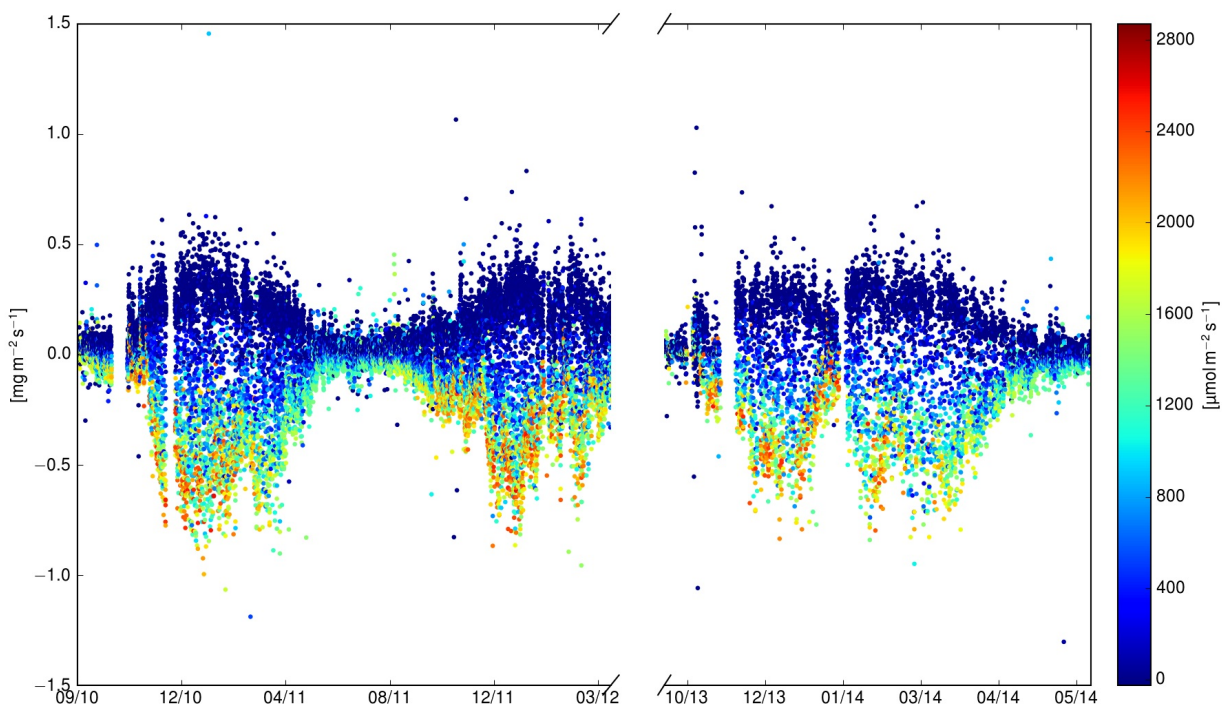

Figure 4. Micrometeorological $\mathrm{CO}_{2}$ flux measurements at Welgegund (Räsänen et al., 2016). The colour bar indicates the photosynthetic photon flux density (PPFD).

Table 1. Lifetime $(\tau)$ of BVOCs calculated for the average concentration of $\mathrm{OH}$ radicals (ca. $0.04 \mathrm{pptv}$ ) as reported by Ciccioli et al. (2014) and the annual average $\mathrm{O}_{3}$ (ca. $36 \mathrm{ppbv}$ ) concentration measured for the two campaigns at Welgegund.

\begin{tabular}{llrr}
\hline & $\tau_{\mathrm{OH}}$ & $\tau_{\mathrm{O}_{3}}$ \\
\hline & Isoprene & $2.8 \mathrm{~h}$ & 1 day \\
& MBO & $10.3 \mathrm{~h}$ & 7.5 day \\
\hline & $\alpha$-Pinene & $5.3 \mathrm{~h}$ & $3.6 \mathrm{~h}$ \\
& Camphene & $5.3 \mathrm{~h}$ & $14.5 \mathrm{day}$ \\
& $\beta$-Pinene & $3.6 \mathrm{~h}$ & $20.9 \mathrm{~h}$ \\
& $\Delta^{3}$-Carene & $3.2 \mathrm{~h}$ & $8.5 \mathrm{~h}$ \\
& p-Cymene & $18.8 \mathrm{~h}$ & $261.6 \mathrm{day}$ \\
& 1,8-Cineol & $12.5 \mathrm{~h}$ & - \\
Monoterpenes & Limonene & $1.7 \mathrm{~h}$ & $1.6 \mathrm{~h}$ \\
& Terpinolene & $12.6 \mathrm{~h}$ & $2.3 \mathrm{~h}$ \\
& AMCH & $2.9 \mathrm{~h}$ & - \\
& Nopinene & $1.4 \mathrm{day}$ & - \\
& Bornylacetate & $1.5 \mathrm{day}$ & - \\
& 4-Allylanisole & $5.2 \mathrm{~h}$ & $1.1 \mathrm{day}$ \\
\hline \multirow{5}{*}{ Sesquiterpenes } & Longicyclene & $1.3 \mathrm{day}$ & - \\
& iso-Longifolene & $2.9 \mathrm{~h}$ & $1.1 \mathrm{day}$ \\
& Aromadendrene & $4.5 \mathrm{~h}$ & 1.1 day \\
& $\alpha$-Humulene & $1 \mathrm{~h}$ & $21.6 \mathrm{~min}$ \\
\hline
\end{tabular}

BVOC species determined during the two sampling campaigns at Welgegund are presented. It is evident from the median (mean) daytime to night-time concentration ratios that there were not significant differences in levels of most of the BVOCs measured during daytime and night-time at Welgegund, with the exception of isoprene measured during the first sampling campaign, as well as the monoter- penes terpinolene and bornylacetate, and the SQT aromadendrene measured during the second sampling campaign. Isoprene levels during the first sampling campaign were approximately 2 times higher during daytime, which reflect the light dependency usually associated with isoprene emissions. However, daytime to night-time concentration ratios of isoprene did not exhibited the strong light dependency typically associated with atmospheric isoprene concentrations, which could be attributed to the characteristics of sources of these species that are discussed in subsequent sections. The temperature and photoactive radiation (PAR) measurements at Welgegund were used in the MEGAN BVOC emission model, which indicated that the measurement time (11:00 to 13:00 LT) captured most of the period of maximum isoprene emission (typically about 12:00 to 02:00 LT). In addition, by assuming a typical diurnal variation in VOC oxidation rate and boundary layer height, it was also found that the isoprene concentration of the measurement time is representative of the daytime isoprene concentration (Greenberg et al., 1999). In Table 3, the concentrations of BVOC species measured during other campaigns in South Africa and the rest of the world are presented.

The most abundant species observed throughout the study was the monoterpene, $\alpha$-pinene, and the total monoterpene concentration was at least an order of magnitude higher compared to the concentrations of other BVOC categories. The total annual median (IQR) monoterpene concentration was 120 (73-242) pptv during the first campaign and 83 (54145) pptv during the second campaign. As indicated in Table 2, $\alpha$-pinene, p-cymene and limonene were the predominant compounds measured during the first campaign, constituting more than $63 \%$ of the ambient monoterpene concentrations, while during the second campaign, the domi- 
Table 2. The ambient BVOC concentration for the two campaigns measured at Welgegund.

\begin{tabular}{|c|c|c|c|c|c|c|c|c|}
\hline & \multicolumn{4}{|c|}{ First campaign } & \multicolumn{4}{|c|}{ Second campaign } \\
\hline & $\begin{array}{r}\text { Median } \\
\text { (mean) }\end{array}$ & $\begin{array}{r}\mathrm{IQR} \\
(25-75 \mathrm{th})\end{array}$ & $\begin{array}{r}\text { Median } \\
\text { day/night ratio }\end{array}$ & $N$ & $\begin{array}{r}\text { Median } \\
\text { (mean) }\end{array}$ & $\begin{array}{l}\text { IQR } \\
(25-75 \text { th })\end{array}$ & $\begin{array}{r}\text { Median } \\
\text { day/night ratio }\end{array}$ & $N$ \\
\hline Isoprene & $14(28)$ & $6-35$ & $2.01(1.7)$ & 187 & $14(23)$ & $7-24$ & $0.99(1.31)$ & 175 \\
\hline $\mathrm{MBO}$ & $7(12)$ & $3-16$ & $0.94(0.91)$ & 178 & $4(8)$ & $3-10$ & $1.13(1.20)$ & 163 \\
\hline \multicolumn{9}{|l|}{ Monoterpenes } \\
\hline$\alpha$-Pinene & $37(71)$ & $28-83$ & $1.14(0.93)$ & 197 & $15(57)$ & $9-23$ & $1.23(1.09)$ & 191 \\
\hline Camphene & $4(8)$ & $2-9$ & $1.26(1.08)$ & 178 & $2(4)$ & $1-3$ & $1.20(0.88)$ & 113 \\
\hline$\beta$-Pinene & $9(19)$ & $5-18$ & $1.11(0.98)$ & 195 & $3(5)$ & $2-6$ & $1.31(1.23)$ & 171 \\
\hline$\Delta^{3}$-Carene & $3(6)$ & $2-5$ & $1.52(1.13)$ & 156 & $2(4)$ & $1-4$ & $1.13(0.71)$ & 58 \\
\hline 1,8-Cineol & $3(13)$ & $1-7$ & $1.04(0.92)$ & 162 & $1(2)$ & $1-2$ & $0.94(0.77)$ & 75 \\
\hline Limonene & $21(30)$ & $9-40$ & $1.24(1.04)$ & 197 & $16(54)$ & $8-36$ & $1.23(0.96)$ & 187 \\
\hline Terpinolene & $4(14)$ & $3-11$ & $1.35(1.02)$ & 141 & $22(28)$ & $16-34$ & $1.57(1.60)$ & 25 \\
\hline Nopinene & $6(7)$ & 4-9 & $1.13(1.09)$ & 167 & $8(11)$ & $6-13$ & $1.31(1.26)$ & 176 \\
\hline Bornylacetate & $1(2)$ & $1-2$ & $1.19(1.08)$ & 49 & $2(3)$ & $1-3$ & $1.40(1.82)$ & 101 \\
\hline \multicolumn{9}{|l|}{ Monoterpene-related BVOCs } \\
\hline p-Cymene & $20(48)$ & $12-33$ & $1.08(0.96)$ & 197 & $7(15)$ & $4-13$ & $1.20(0.97)$ & 186 \\
\hline 4-Allylanisole & $8(11)$ & $5-13$ & $1.26(0.96)$ & 118 & $1(12)$ & $1-3$ & $1.32(0.59)$ & 70 \\
\hline $\mathrm{AMCH}$ & $5(7)$ & $1-12$ & $0.28(0.64)$ & 41 & $3(4)$ & $2-5$ & $1.33(1.29)$ & 24 \\
\hline $\begin{array}{l}\Sigma \text { monoterpenes and } \\
\text { monoterpene-related BVOCs }\end{array}$ & $120(235)$ & $73-242$ & & & $83(198)$ & $54-145$ & & \\
\hline \multicolumn{9}{|l|}{ Sesquiterpenes } \\
\hline Longicyclene & $2(4)$ & $1-4$ & $1.32(1.19)$ & 152 & $1(2)$ & $1-3$ & $0.95(0.65)$ & 34 \\
\hline iso-Longifolene & $2(3)$ & $1-4$ & $1.06(0.89)$ & 52 & $1(1)$ & 1 & $1.19(1.39)$ & 7 \\
\hline Aromadendrene & $1(1)$ & 1 & & 2 & $2(2)$ & $1-3$ & $1.65(1.91)$ & 73 \\
\hline$\alpha$-Humulene & $1(1)$ & 1 & & 3 & $1(3)$ & $1-5$ & $0.86(3.53)$ & 4 \\
\hline Alloaromadendrene & $2(3)$ & $1-4$ & $0.96(0.84)$ & 31 & & & & \\
\hline$\Sigma$ Sesquiterpenes & $8(12)$ & $5-14$ & & & $4(8)$ & $3-11$ & & \\
\hline
\end{tabular}

nant monoterpenes were $\alpha$-pinene, limonene and terpinolene, constituting more than $70 \%$ of the ambient monoterpene concentrations. BVOC flux measurements conducted by Greenberg et al. (2003) during SAFARI 2000 at a mopane woodland in Botswana indicated that $60 \%$ of the monoterpene flux was attributed to $\alpha$-pinene, while limonene and $\beta$ pinene contributed almost all of the rest of the monoterpenes. Various studies in other regions have also indicated that $\alpha$ pinene is the dominant monoterpene in ambient air reflecting the ubiquitous nature of its emission (Hellén et al., 2012b; Hakola et al., 2012; Noe et al., 2012). During the AMMA experiment, Saxton et al. (2007) also detected several monoterpenes in ambient air at Djougou with concentrations generally higher than monoterpene concentrations recorded by Serca et al. (2001) (less than 20 pptv) during EXPRESSO at a forest in northern Congo. Monoterpene concentrations reported for boreal forest (Hakola et al., 2009, 2000; Rinne et al., 2000, 2005; Rantala et al., 2015; Räisänen et al., 2009; Eerdekens et al., 2009; Lappalainen et al., 2009), hemiboreal mixed forest (Noe et al., 2012), temperate (Spirig et al.,
2005; Stroud et al., 2005; Fuentes et al., 2007; Mielke et al., 2010), Mediterranean (Davison et al., 2009; Harrison et al., 2001) and tropical (Rinne et al., 2002) ecosystems ranged between 40 and 7200 pptv (Table 3). Therefore, there is a large variation in the monoterpene concentrations measured in different ecosystems, with concentrations measured at Welgegund being in the low to mid-range. Unlike isoprene that is approximately 10 times lower than isoprene levels at other ecosystems in the world, the mean monoterpene concentration at Welgegund is comparable to the previous studies at other ecosystems summarized in Table 3.

The annual median (IQR) isoprene concentration measured during the first campaign was 14 (6-35) pptv, while the annual median (IQR) isoprene concentration measured during the second sampling campaign was 14 (7-24) pptv. The highest isoprene concentration, i.e. $202 \mathrm{pptv}$, was recorded in summer (wet season). Harley et al. (2003) reported that the maximum isoprene concentration measured during an 8-day campaign in the wet season at a Combretum-Acacia savannah in southern Africa was 860 pptv with a mean midday 
Table 3. Ambient BVOC concentrations (pptv) as reported by Noe et al. (2012) for various ecosystems and then modified: avg - mean value, med - median value, and max - maximal value of the measurements reported.

\begin{tabular}{|c|c|c|c|c|c|}
\hline Location & Isoprene & MBO & Monoterpenes & Date & References \\
\hline \multicolumn{6}{|c|}{ Grassland } \\
\hline \multirow[t]{2}{*}{ Welgegund, SA } & 28 (avg), $202(\max )$ & 12 (avg), $61(\max )$ & 235 (avg), 1744 (max) & Feb 2011-Feb 2012 & this study \\
\hline & 23(avg), 182 (max) & 7 (avg), 47 (max) & 198 (avg), 3081 (max) & Dec 2013-Feb 2015 & this study \\
\hline \multicolumn{6}{|c|}{ Savannah } \\
\hline KNP, SA & 390 (avg), 860 (max) & & \multirow{3}{*}{$>5000(\max )$} & Feb 2001 & Harley et al. (2003) \\
\hline Benin & $>3000(\max )$ & & & 7-13 Jun 2006 & Saxton et al. (2007) \\
\hline Village, Senegal & 300 (avg) & & & Sep 2006 & Grant et al. (2008) \\
\hline \multicolumn{6}{|c|}{ Boreal } \\
\hline \multirow[t]{8}{*}{ Hyytiälä, Finland } & & & 900 (avg), 1800 (max) & 2000-2007 & Hakola et al. (2009) \\
\hline & $40-110$ & & $100-700$ & Apr 2005 & Eerdekens et al. (2009) \\
\hline & 220 (med), 360 (max) & & 300 (med), $600(\max )$ & Summer 2006/2007 & Lappalainen et al. (2009) \\
\hline & 70 (med), $110(\max )$ & & 200 (med), $300(\max )$ & Winter 2006/2007 & \\
\hline & $110(\operatorname{avg}), 430(\max )$ & & 100 (avg), 2700 (max) & Jul 2004 & Rinne et al. (2005) \\
\hline & & & $40-450$ & 37 m, Aug 1998 & Rinne et al. (2000) \\
\hline & & & $140-500$ & 19.5 m, Aug 1998 & \\
\hline & & & $450-630$ & 2 m, Aug 1998 & \\
\hline Huhus, Finland & & & 900 (avg), 2160 (max) & Jun-Sep 2003 & Räisänen et al. (2009) \\
\hline Pötsönvaara, Finland & $320-1690$ & & $1700-3200$ & Apr-Oct 1997, 1998 & Hakola et al. (2000) \\
\hline \multicolumn{6}{|c|}{ Hemiboreal } \\
\hline \multirow[t]{2}{*}{ Järvselja, Estonia } & $360-2520$ & & $1800-7200$ & Spring and summer 2010 & Noe et al. (2012) \\
\hline & $120-200$ (med) & & 400-1400 (med) & Oct 2009-Sep 2010 & Noe et al. (2012) \\
\hline \multicolumn{6}{|c|}{ Temperate } \\
\hline Michigan, USA & 2520 (avg), $8160(\max )$ & & 310 (avg), $1100(\max )$ & Summer 2008 & Mielke et al. (2010) \\
\hline Jülich, Germany & 1980 (avg), 10790 (max) & & 250 (avg), 1470 (max) & Jul 2003 & Spirig et al. (2005) \\
\hline Duke Forest, USA & $1500-2200$ & & $310-790$ & Jul 2003 & Stroud et al. (2005) \\
\hline Oak Ridge, USA & $5000-15000$ & & $500-1600$ & Jul 1999 & Fuentes et al. (2007) \\
\hline MEF, USA & 70 (avg) & 1346 (avg) & 0.497 (avg) & 22-28 Aug 2008 & Nakashima et al. (2014) \\
\hline \multicolumn{6}{|c|}{ Mediterranean } \\
\hline Castelpoziano, Italy & $141-250$ & & $100-200$ & May-Jun 2007 & Davison et al. (2009) \\
\hline AM, Greece & 1500 (avg), 7900 (max) & & 900 (avg), 5000 (max) & Jul-Aug 1997 & Harrison et al. (2001) \\
\hline \multicolumn{6}{|c|}{ Tropical } \\
\hline FNT, Brazil & 2000 (avg), $4000(\max )$ & & 50 (avg), $130(\max )$ & Jul 2000 & Rinne et al. (2002) \\
\hline NNNP, NC & $1820 \pm 870$ & & & 16-24 Mar 1996 & Serca et al. (2001) \\
\hline & $730 \pm 480$ & & & 21 Nov-11 Dec 1996 & \\
\hline
\end{tabular}

SA: South Africa; WA: West Africa; KNP: Kruger National Park; MEF: Manitou Experimental Forest; AM: Agrafa Mountains; FNT: Floresta Nacional do Tapajos; NNNP: Nouabalé-Ndoki National Park; NC: northern Congo.

concentration of $390 \mathrm{pptv}$, which is considerably higher than isoprene levels measured at Welgegund. Ambient BVOC measurements conducted by Saxton et al. (2007) at a rural site near Djougou, Benin, in June 2006 during the AMMA project indicated isoprene concentrations $>3000 \mathrm{pptv}$. Grant et al. (2008) conducted VOC measurements at a small rural Senegalese village during September 2006 that was also a sampling location for the AMMA project and reported that isoprene, which had a mean concentration of $300 \pm 100 \mathrm{pptv}$, was the only biogenic hydrocarbon present in all air samples. Serca et al. (2001) reported the ambient mean isoprene concentration for a tropical forest of northern Congo during the EXPRESSO study to be $1820 \pm 870 \mathrm{pptv}$ at the beginning of the wet season and $730 \pm 480 \mathrm{pptv}$ at the end of the wet season. Nakashima et al. (2014) reported that the mean isoprene concentration at the Manitou Experimental Forest (MEF) was $68 \pm 69$ pptv. In general, mean isoprene concentrations measured at Welgegund were at least an order of magnitude smaller compared to other isoprene measurements in South Africa, Africa and most other parts of the world.

The annual median (IQR) MBO concentrations measured during the first and second campaign were 7 (3-16) and 4 (310) pptv, respectively. MBO and isoprene are both produced from dimethylallyl diphosphate (Gray et al., 2011). Guenther (2013) indicated that MBO is emitted from most isoprene emitting vegetation at an emission rate of $\sim 1 \%$ of that 
of isoprene. However, MBO measured at Welgegund was approximately $30 \%$ of the isoprene concentrations, which indicated that the main source of MBO at Welgegund is not from isoprene emitters, but from other MBO emitters. MBO concentration measurements at Manitou Experimental Forest, USA, were $1346 \pm 777$ pptv (Nakashima et al., 2014), which is 3 orders of magnitude higher compared to the MBO levels measured at Welgegund. To the best of the authors' knowledge, there are no previous ambient MBO concentrations measured for Africa.

Most SQTs are highly reactive species and are difficult to detect in ambient air samples, which resulted in concentrations of these species being frequently below the detection limit of the analytical procedure. This is also reflected in the concentrations of these species being an order of magnitude lower compared to the other BVOC species measured in this study. The total annual median (IQR) SQT concentration measured during the first sampling campaign was 8 (5-14) pptv and 4 (3-11) pptv during the second sampling campaign. The most abundant SQT during the first sampling campaign was longicyclene with an annual mean concentration of $4(1-4)$ pptv. During the second sampling campaign, $\alpha$-humulene was the most abundant SQT with an annual mean concentration of $3(1-5)$ pptv.

The lower BVOC concentrations measured at Welgegund compared to other regions can mainly be attributed to the much lower isoprene concentrations measured. However, monoterpenes that are important for SOA formation are similar to levels thereof in other environments. In an effort to explain the BVOC concentrations measured at Welgegund, a comprehensive vegetation study was conducted, as described in Sect. 2.2. The influence of the type of vegetation in the region surrounding Welgegund on ambient BVOC concentrations will be further explored.

Jaars et al. (2014) presented concentrations of aromatic VOCs measured at Welgegund during the same two sampling campaigns discussed in this paper. The total BVOC concentrations measured were at least an order of magnitude lower compared to concentrations of aromatic VOCs measured at Welgegund. The most abundant aromatic compound, toluene, had a median value of $630 \mathrm{pptv}$, whereas the most abundant BVOC measured, $\alpha$-pinene, had a median value of 37 pptv. In addition, the median of the concentrations of the all the monoterpene species (120 and 83 pptv) was approximately 6 times lower compared to toluene concentrations (Jaars et al., 2014).

\subsection{Seasonal variations}

In Fig. 5, the panels on the left show monthly median concentrations of (a) isoprene, (b) MBO, (c) monoterpene and (d) SQT measured for the two campaigns, while the panels on the right present the wet (October to April) and dry (May to September) season concentrations of the respective compounds measured for the two campaigns. As indi- cated in Sect. 3.2, isoprene measured during the first sampling campaign had higher median (mean) daytime concentrations compared to median (mean) night-time concentrations, which reflects the light dependency expected from isoprene. All other BVOCs with the exception of two monoterpenes and one SQT did not indicate significant differences between daytime and night-time median (mean) concentrations. Therefore, the seasonal plots of only isoprene were separated between daytime and night-time median concentrations. Seasonal variations in BVOC concentrations are expected due to the response of emissions to changes in environmental conditions, e.g. temperature and rainfall, as discussed in Sect. 3.1, and the associated biogenic activity. In addition, BVOC emission is expected to be lower during the winter months (June to August), since foliar densities rapidly decrease due to deciduous trees dropping their leaves in winter (Otter et al., 2002). As expected, it is evident that the concentrations of all the BVOC species, with the exception of the isoprene (Fig. 5a), and SQT values (Fig. 5d) measured during the second sampling campaign, were higher in the wet season. The wet season also had more occurrences of BVOC concentrations that were higher than the range of the box and whisker plots (whiskers indicating $\pm 2.7 \sigma$ or $99.3 \%$ coverage if the data have a normal distribution). In an isoprene and monoterpene emissions modelling study for southern Africa conducted by Otter et al. (2003), it was estimated that BVOC emissions will decrease by as much as $85 \%$ in the dry winter season for grassland and savannah regions. BVOC concentrations measured in this study indicated much lower decreases from summer (December to February) to winter (June to August), with isoprene and monoterpene decreasing by only 37 and $29 \%$, respectively, during the first sampling campaign, while isoprene and monoterpene decreased by only 42 and $23 \%$, respectively, during the second sampling campaign. This can partially be attributed to the significant transformation of this biome, as discussed in Sect. 2.2, with large areas transformed to cultivated land, as indicated in Fig. 2. In addition, the study by Otter et al. (2003) was conducted for the entire southern African region.

The monthly median isoprene concentrations (Fig. 5a) measured during the first sampling campaign indicated the expected seasonal pattern with higher isoprene concentrations coinciding with the wet and warmer months, with the exception of April with had lower isoprene concentrations. Surprisingly, during the second sampling campaign, there was no distinct seasonal pattern observed. However, higher isoprene concentrations seem to coincide with higher wind speeds (Fig. 3d), which are observed for both sampling campaigns. This indicates that the major sources of isoprene measured at Welgegund can be considered not to be within close proximity. However, since oxidation products of isoprene (e.g. methyl vinyl ketone, methacrolein) were not measured in this study, more distant sources of isoprene could not be verified. It is evident from Fig. 2 that the region in close proximity to Welgegund in the south-western to north-eastern 

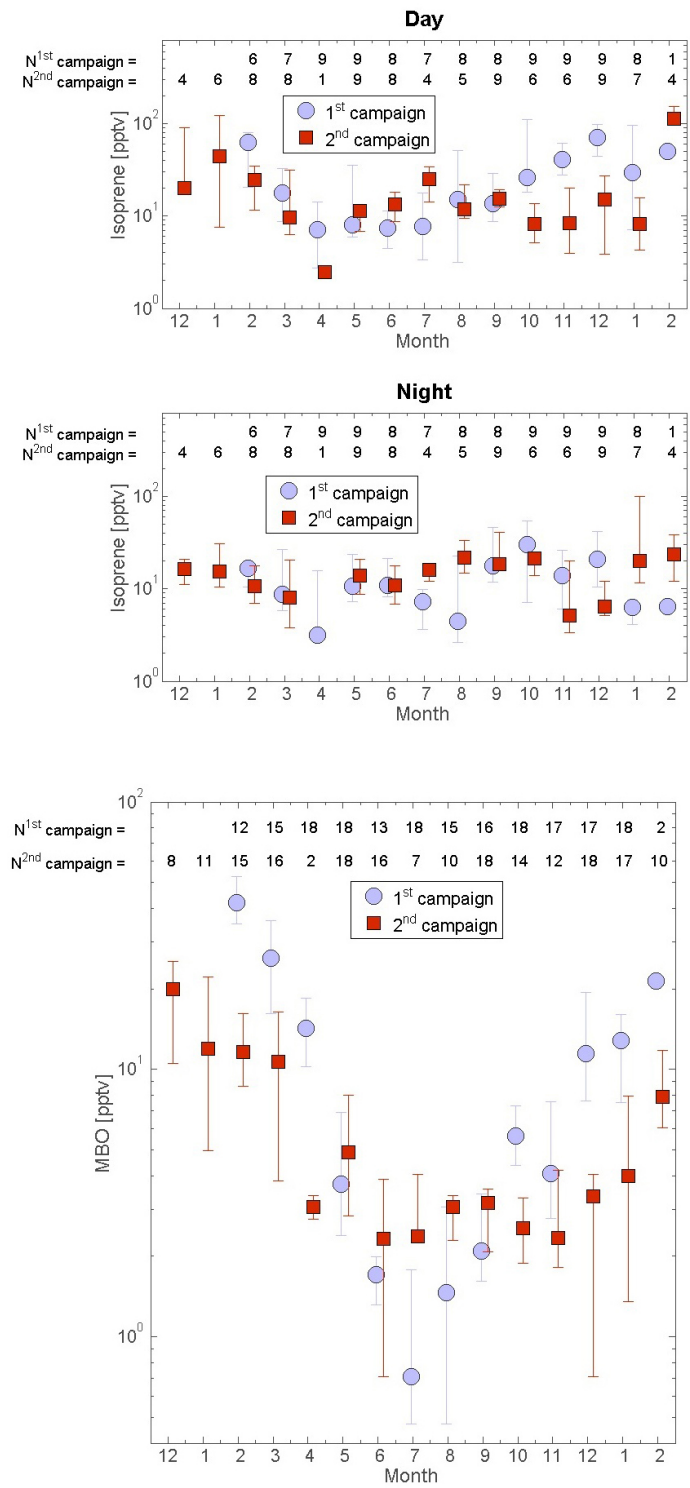

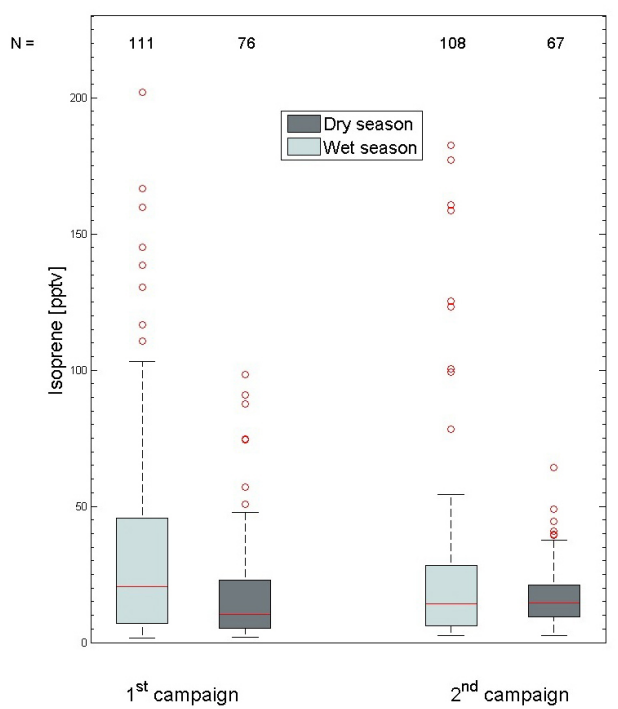

(b)

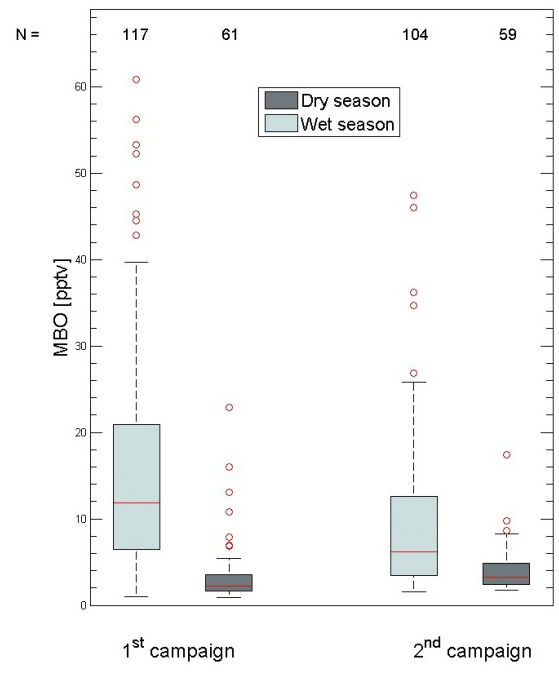

Figure 5.

sectors largely comprises cultivated land, while in the northeastern to south-western sectors the predominant land coverage is grassland and natural vegetation. It is expected that isoprene emissions from the cultivated land will be lower compared to savannah grassland (Otter et al., 2003). Therefore, if Welgegund is more frequently affected by winds from the south-western to north-eastern sectors, higher wind speeds will coincide with higher isoprene levels, since the savannah grassland fetch region is distant from Welgegund and related to the approximately $3 \mathrm{~h}$ atmospheric lifetime of isoprene due to $\mathrm{OH}$ radicals.

In Fig. 6, the wind roses for the BVOCs species measured in this study are presented. It is evident that the highest isoprene concentrations for the first sampling period were associated with winds originating from the south to south-western sector, i.e. predominantly from the grassland region in close proximity during the first sampling campaign resulting in a relatively more distinct seasonal pattern for isoprene levels. During the second sampling campaign, higher isoprene concentrations were associated with winds originating from the south-western to the northern sector, i.e. from the cultivated land area. Therefore, isoprene concentrations measured during the second sampling period coincided predominantly with stronger wind speeds from more distant fetch regions.

Distinct seasonal patterns are observed for MBO (Fig. 5b) concentrations during both sampling campaigns, i.e. higher MBO concentrations coinciding with wet warm months and lower levels corresponding with dry cold months (Fig. 3). The MBO concentrations also corresponded to the seasonal $\mathrm{CO}_{2}$ uptake (Fig. 4). It is also evident from Fig. 5b that 


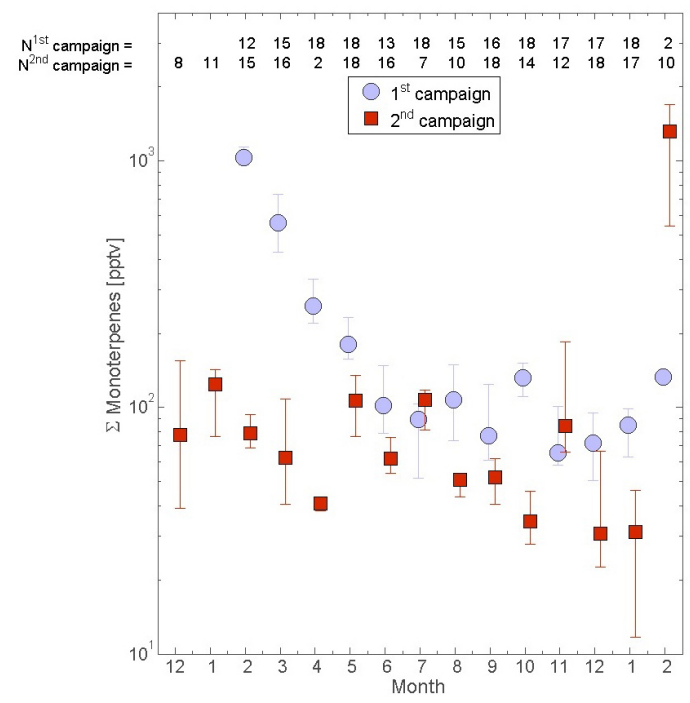

(c)

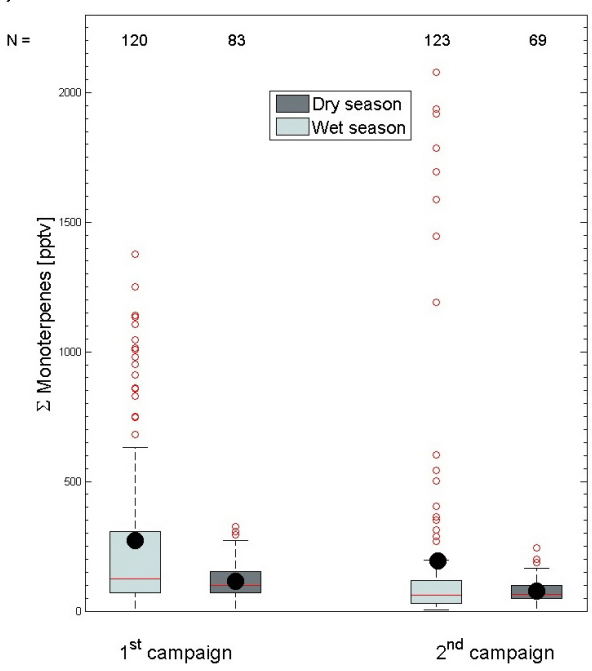

(d)
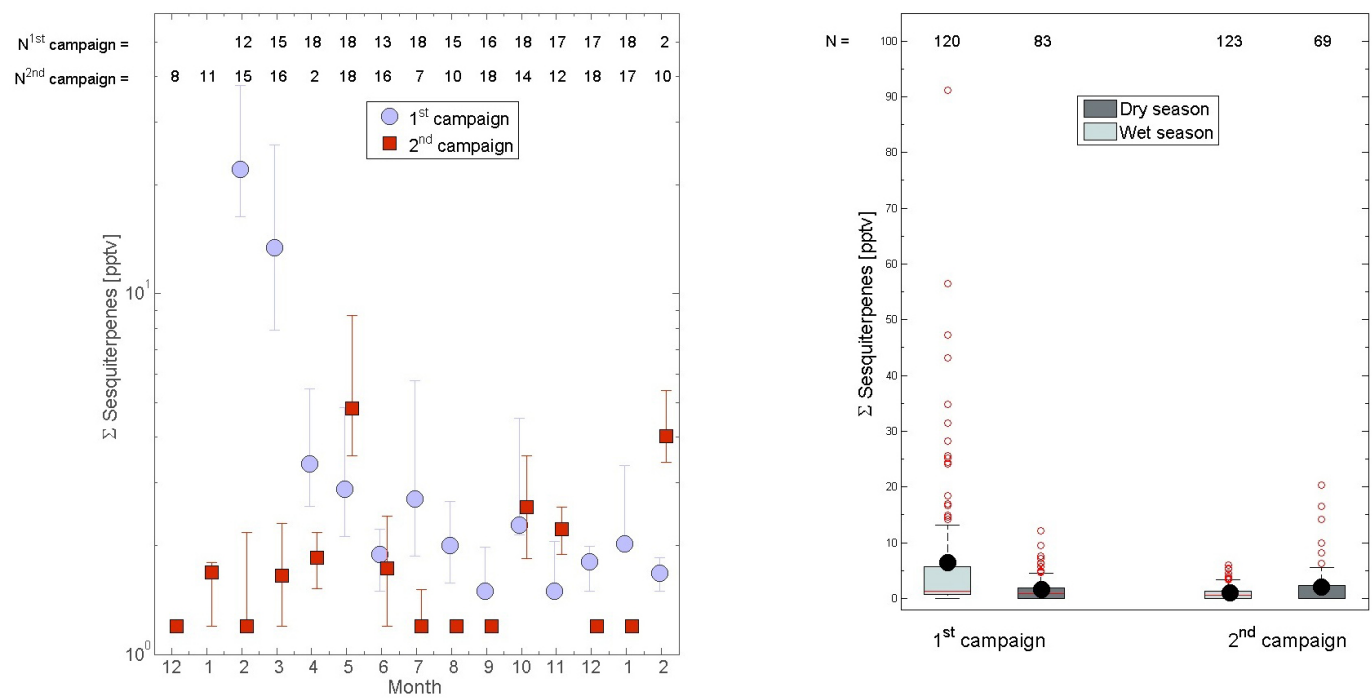

Figure 5. The panels on the left show monthly median concentrations of (a) isoprene, (b) MBO, (c) monoterpene and (d) SQT measured for the two campaigns. Error bars indicate upper and lower quartiles. The values displayed near the top of the graphs indicate the number of samples ( $\mathrm{N}^{1 \mathrm{st}}$ and $\mathrm{N}^{2 \mathrm{nd}}$ campaign) analysed for each month. The panels on the right show the wet and dry season concentrations of the respective compounds measured for the two campaigns. The red line of each box indicates the median (50th percentile), the black dot the mean, the top and bottom edges of the box the 25 th and 75 th percentiles, the whiskers $\pm 2.7 \sigma$ or $99.3 \%$ coverage if the data have a normal distribution and the red circles outliers of the range of the box and whisker plot. The values displayed near the top of the graphs indicate the number of samples $(N)$ analysed for the wet and dry season.

MBO concentrations during the wet season in the first sampling campaign were higher compared to the second sampling campaign, especially from February to April 2011. As mentioned in Sect. 3.1, the soil moisture measured at a depth of $20 \mathrm{~cm}$ (Fig. $3 \mathrm{~g}$ ) during the first sampling campaign was significantly higher from February to August compared to the second sampling campaign. Therefore, these increased MBO levels measured during the first sampling campaign can be attributed to increased emissions from deep-rooted plants, e.g. shrubs and trees. In addition to decreased biogenic activity in the dry winter, the conversion of MBO to isoprene in the atmosphere could also lead to decreased MBO levels during this period. Jaoui et al. (2012) reported that MBO conversion to isoprene increased by an order of magnitude during dry conditions compared to humid conditions. This can also contribute to elevated isoprene concentrations measured during the dry months at Welgegund (Fig. 5a). 


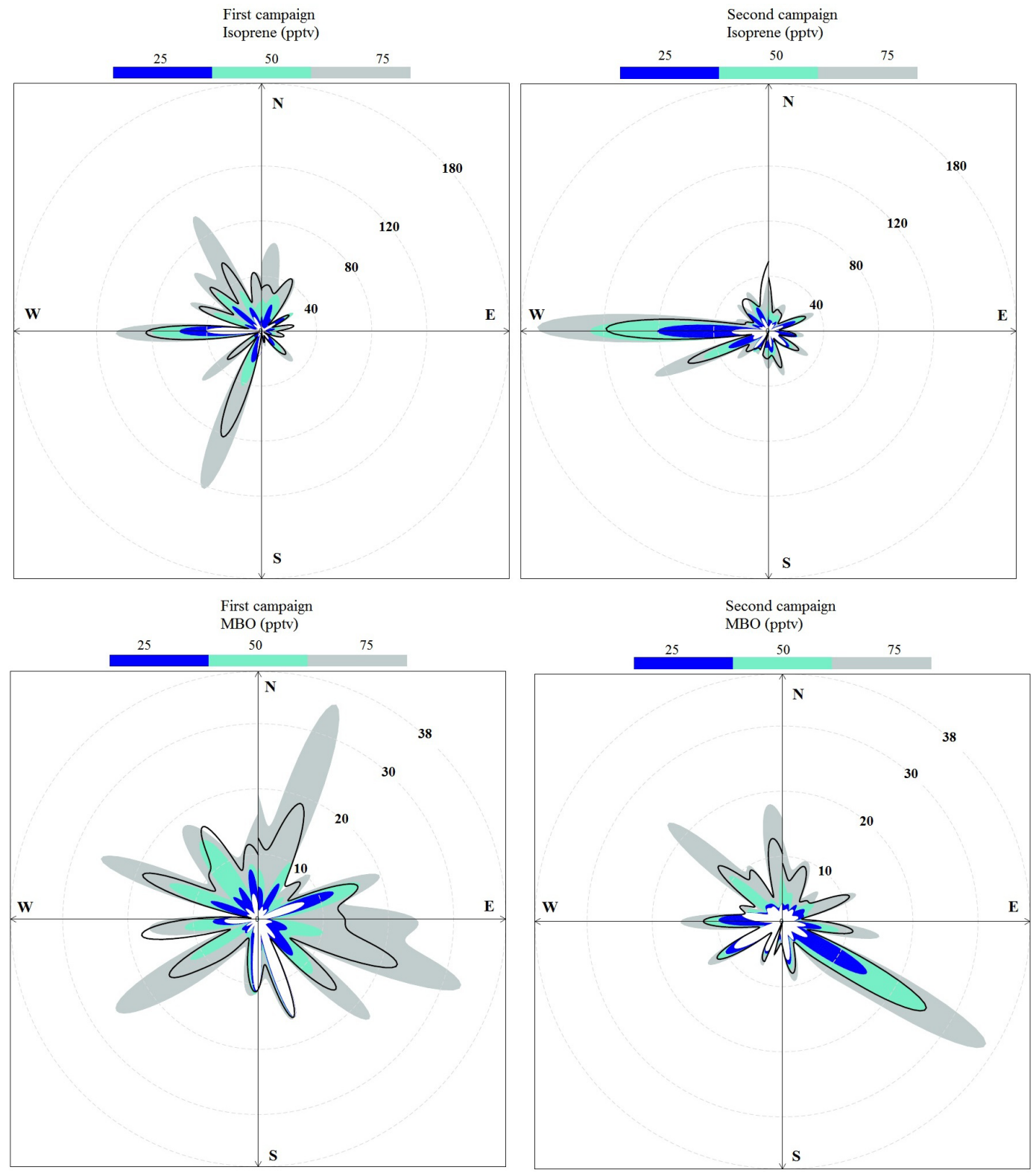

Figure 6.

No distinct seasonal pattern is observed for monoterpene and SQT concentrations, with the exception of significantly higher levels measured from February to April 2011 during the first sampling campaign. These increased monoterpene and SQT concentrations can also be attributed to the significantly higher soil moisture measured at a depth of $20 \mathrm{~cm}$ during the first sampling campaign (Fig. 3g), as observed for the MBO. The monoterpene and SQT concentrations measured during the first sampling campaign were generally higher compared to the second sampling campaign. In Fig. S1a and b in the Supplement, the relationship between soil moisture and monoterpene concentrations, as well as between soil moisture and SQT are presented, respectively. It is evident that higher concentrations of monoterpene and SQT are associated with higher soil moisture measured at a depth of 5 and $20 \mathrm{~cm}$. Otter et al. (2002) also reported a more pronounced seasonal pattern for isoprene compared to monoterpene emissions at the Nylsvley Nature Reserve, which is approximately $200 \mathrm{~km}$ north-west of Welgegund.

\subsection{BVOC emissions from surrounding vegetation}

As discussed in Sect. 2.2 and indicated in Fig. 2, Welgegund is situated in a region that has been significantly transformed through cultivation. Cultivated land within the demarcated $60 \mathrm{~km}$ radius (Fig. 2) consists mainly of maize and, to a 




Figure 6. BVOC concentration rose at Welgegund for the two sampling campaigns. Different colours represent percentiles: blue - $25 \%$, aquamarine $-50 \%$, azure $-75 \%$, and the black solid line represents the average.

lesser degree, sunflower production. These cultivated lands are also typically characterized by eucalyptus trees, which have a very high BVOC emission potential (Kesselmeier and Staudt, 1999), planted on their peripheries as is evident in Fig. 2. The grassland region in close proximity to Welgegund (south-western to north-eastern sector) has a high diversity of grass and woody species, as mentioned in Sect. 2.2. In general, it can be considered that the woody species in the grasslands are major sources of all the BVOCs measured in this study. Otter et al. (2003) also considered woody vegetation to be the most important in terms of BVOC emissions in southern Africa. It is generally considered that crops and grass have very low isoprene-emitting capacities (Kesselmeier and Staudt, 1999; Guenther, 2013). However, Schuh et al. (1997) indicated that sunflowers emit isoprene; the monoterpenes $\alpha$-pinene, $\beta$-pinene, sabinene, 3 -carene and limonene; and the sesquiterpene $\beta$-caryophyllene predominantly. In addition, Chang et al. (2014) (with references therein) also indicated that isoprene has anthropogenic sources in urban areas, which indicates that the surrounding towns can also contribute to the isoprene concentrations.

In an effort to determine possible sources of BVOC species, concentrations roses were compiled, as presented in Fig. 6. In general, the concentration roses indicated that 
(a)


(b)
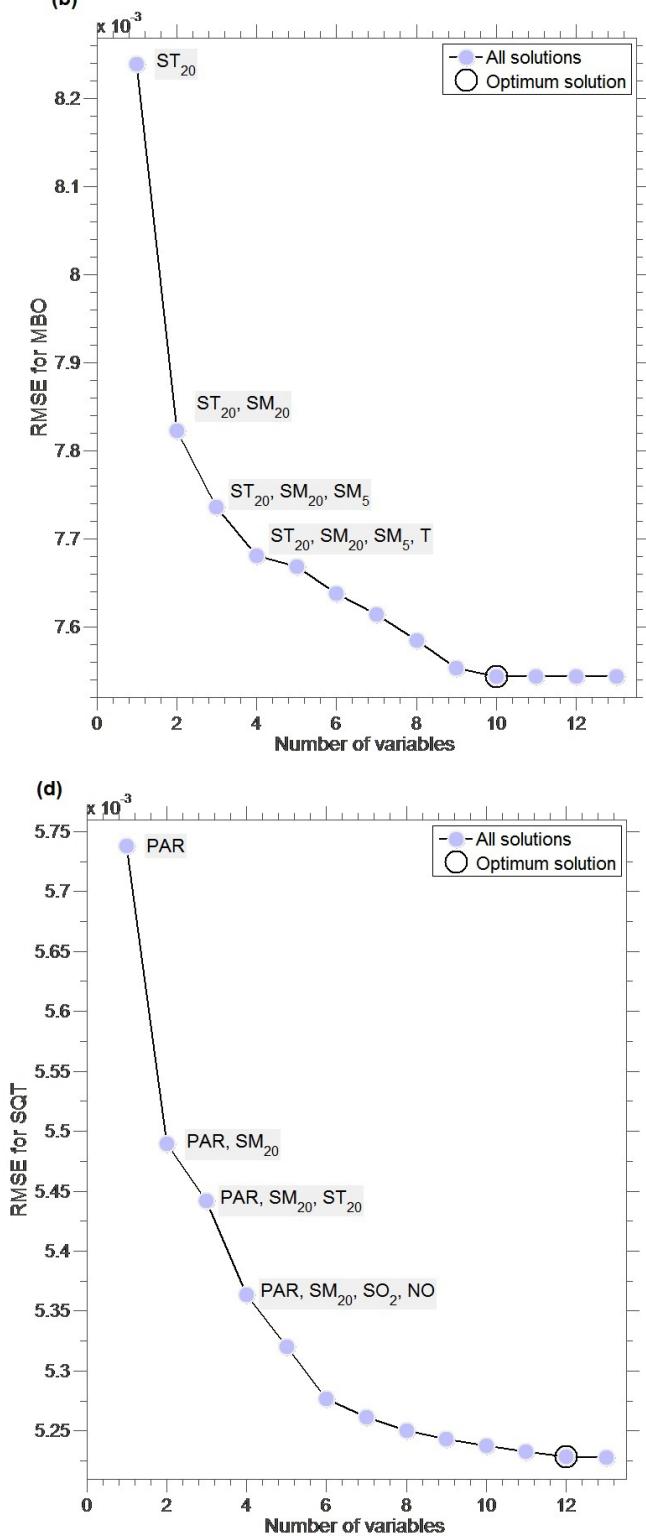

Figure 7. The optimum combination of independent variables to include in a MLR equation to calculate the dependant variable, i.e. BVOC concentrations. The root mean square error (RMSE) difference between the calculated and measured concentrations indicated that the inclusion of (a) 9 parameters for isoprene, (b) 10 parameters for MBO, (c) 7 parameters for MT, and (d) 12 parameters for SQT in the MLR solution was the optimum.

isoprene concentrations were higher from the western sector (indicated by the average and highest concentrations) that is considered to be a relatively clean regional background region with no large anthropogenic point sources (Fig. 1), while wind direction did not indicate any significant differences in the concentrations of the other BVOC species. On occasion, higher MBO, monoterpene and SQT concentrations were observed from the south-eastern region, which may be attributed to a large eucalyptus plantation approximately $15 \mathrm{~km}$ south-east of Welgegund, indicated in Fig. 2.
However, high isoprene emissions are also usually associated with eucalyptus trees, which are not observed in the isoprene concentration roses. Therefore, other sources of $\mathrm{MBO}$, monoterpene and SQT in these regions are most likely to be the main sources, which can possibly include the urban footprint indicated in this region. In addition, pine trees are common foreign tree species that are planted on farms in this region (Rouget, 2002), which could be potential sources of $\mathrm{MBO}$ and monoterpenes. 
Table 4. Spearman's correlation coefficients between the BVOCs during the wet and dry season of the first campaign (a) and second campaign (b).

\begin{tabular}{llrrrr}
\hline \multicolumn{7}{c}{ (a) Dry season } & & \\
\hline \multirow{6}{*}{ Wet season } & Isoprene & - & $\mathbf{0 . 5 2}$ & $\mathbf{0 . 0 3}$ & $-\mathbf{- 0 . 1 0}$ \\
& MBO & 0.09 & - & $\mathbf{0 . 5 7}$ & $-\mathbf{0 . 1 0}$ \\
& MT & -0.20 & 0.68 & - & $\mathbf{0 . 2 7}$ \\
& SQT & -0.04 & 0.56 & 0.80 & - \\
\hline & & (b) Dry season & MBO & Monoterpene & SQT \\
\hline \multirow{6}{*}{ Wet season } & Isoprene & - & $\mathbf{0 . 3 9}$ & $-\mathbf{0 . 1 1}$ & $\mathbf{0 . 0 9}$ \\
& MBO & 0.50 & - & $\mathbf{0 . 3 9}$ & $\mathbf{0 . 4 8}$ \\
& MT & 0.27 & 0.38 & - & $\mathbf{0 . 6 0}$ \\
& SQT & 0.20 & 0.01 & 0.26 & - \\
\hline
\end{tabular}

The similar concentration roses determined for monoterpenes and SQTs during the first sampling campaign can be attributed to similar sources of these species. However, most SQTs have short atmospheric lifetimes $(<4 \mathrm{~min})$ (Atkinson and Arey, 2003a), which indicated similar sources within close proximity $(\sim 1-2 \mathrm{~km}$ radius $)$ of Welgegund. Gouinguené and Turlings (2002) indicated the emissions of several SQTs from young maize plants by testing the effects of soil humidity, air humidity, temperature, light and fertilization rate on the emission of BVOCs from these plants. Therefore, maize production may be a source of monoterpenes and SQTs. The higher SQT concentrations in the south-west and north-west can most likely be attributed to smaller eucalyptus plantations within a 1 to $2 \mathrm{~km}$ radius, as indicated in Fig. 2. The high monoterpene concentrations determined during the second sampling campaign may be associated with specific monoterpene emitting plants in the region.

Floral emissions could also be considered a potential source of monoterpenes in this region, which could also contribute to the relative abundance of monoterpenes compared to the relatively low isoprene concentrations. Floral emissions in this region would typically occur with the onset of the wet season in October up until February. It is well-known that meadows, i.e. grazed grasslands in South Africa, in this region have a significant number of species that flower. South African grasslands are considered to be exceptionally species rich (Siebert, 2011), since it is ancient, primary grasslands, i.e. not man-made (Bond, 2016).

Of particular interest is the potential sources of 4allylanisole (estragole) due to its relatively substantial levels as indicated in Table 2. Bouvier-Brown et al. (2009) and Misztal et al. (2010) indicated that this species could potentially have a significant contribution to regional atmospheric chemistry due to relatively large estragole emissions measured from ponderosa pine trees and oil palms, respectively. As mentioned previously, pine trees are typically found on farms in this region as intruder tree species (Rouget, 2002), while numerous palm trees are found in cities/towns surrounding Welgegund (Lubbe et al., 2011). In addition, Foeniculum vulgare (fennel) - considered a typical source of estragole - is an abundant and common weed in this study region (Lubbe et al., 2010). Furthermore, estragole emissions could also potentially have a floral origin.

Although a comprehensive vegetation survey has been conducted within a $60 \mathrm{~km}$ radius of Welgegund, vegetation types have been identified only generally at this stage, as indicated in Sect. 2.2. Therefore, the predominant woody species in each of the regions surrounding Welgegund associated with specific BVOC emissions have not yet been characterized.

\subsection{Statistical correlations}

Spearman's correlation analyses were applied to correlate the measured concentrations of isoprene, MBO, monoterpene and SQT measured to each other in order to substantiate sources of these species. These correlations for the two sampling campaigns are presented in Table 4 , with correlations in the wet seasons listed in the lower bottom (not highlighted) and correlations in the dry season presented in the top right (bold highlighted). It is evident that MBO had good correlations with monoterpenes and SQTs in the wet season, as well as with monoterpenes in the dry season during the first sampling campaign. Although not as distinct as during the first sampling campaign, MBO did also correlate with monoterpenes during the wet and dry season, as well as with SQT in the dry season during the second sampling campaign. During the first sampling campaign, monoterpenes had a strong correlation with SQT in the wet season and moderate correlation during the dry season, while strong correlations between monoterpene and SQT were determined in the dry season and a moderate correlation during the wet season during the second sampling campaign. As indicated previously, concentration roses did indicate similar sources of monoterpene and SQT, especially during the first sampling campaign, which is signified by these correlations.

Spearman correlations between BVOCs and other parameters measured at Welgegund did not show significant correlations. However, in certain instances, good correlations were observed between soil moisture and MBO, monoterpene and SQT concentrations. This is expected, since the monthly average concentrations of these species indicated increased levels thereof that were associated with increased soil moisture from February to April 2011. Therefore, in an effort to further statistically explore the data set, explorative MLR (multilinear regression) was performed by using all ancillary measurements as input data in order to indicate parameter interdependencies on the BVOC concentrations measured. In Fig. 7, the root mean square error (RMSE) difference between the calculated and measured BVOC concentrations, as 
Table 5. Photochemical properties of measured BVOCs during the first and second campaign at Welgegund.

\begin{tabular}{|c|c|c|c|c|c|c|c|c|}
\hline & & \multirow[b]{2}{*}{ MIR* } & \multicolumn{2}{|c|}{ First period } & \multicolumn{2}{|c|}{ Second period } & \multicolumn{2}{|c|}{$\left[\mathrm{cm}^{3}\right.$ molecule $\left.{ }^{-1} \mathrm{~s}^{-1}\right]$} \\
\hline & & & Avg & OFP & Avg & OFP & $k_{\mathrm{OH}} \times 10^{12}$ & $k_{\mathrm{O}_{3}} \times 10^{18}$ \\
\hline & Isoprene & 10.28 & 28 & 289 & 23 & 234 & 101.0 & 13.0 \\
\hline & MBO & 4.73 & 12 & 56 & 7.7 & 37 & 27.5 & 1.8 \\
\hline \multirow{12}{*}{ Monoterpenes } & $\alpha$-Pinene & 4.38 & 71 & 313 & 57 & 251 & 53.7 & 86.6 \\
\hline & Camphene & & 7.9 & & 3.8 & & 53.0 & 0.9 \\
\hline & $\beta$-Pinene & 3.38 & 19 & 64 & 4.6 & 16 & 78.9 & 15.0 \\
\hline & $\Delta^{3}$-Carene & 3.13 & 6.1 & 19 & 4.1 & 13 & 88.0 & 37.0 \\
\hline & p-Cymene & 4.32 & 48 & 206 & 15 & 66 & 15.0 & 0.05 \\
\hline & 1,8-Cineol & & 13 & & 1.9 & & 22.6 & \\
\hline & Limonene & 4.4 & 30 & 131 & 54 & 236 & 171.0 & 200.0 \\
\hline & Terpinolene & 6.16 & 14 & 84 & 28 & 170 & 22.5 & 138.0 \\
\hline & $\mathrm{AMCH}$ & & 6.7 & & 4.2 & & 98.6 & 430.0 \\
\hline & Nopinene & & 7.3 & & 11 & & 8.6 & \\
\hline & Bornylacetate & & 1.7 & & 3.1 & & 7.7 & \\
\hline & 4-Allylanisole & & 11 & & 12 & & 54.3 & 12.0 \\
\hline \multirow{5}{*}{ Sesquiterpenes } & Longicyclene & & 4.2 & & 1.7 & & 9.4 & \\
\hline & iso-Longifolene & & 3.0 & & 0.9 & & 96.2 & 11.4 \\
\hline & Aromadendrene & & 1.0 & & 2.4 & & 62.5 & 12.0 \\
\hline & $\alpha$-Humulene & & 0.9 & & 2.7 & & 290.0 & 870.0 \\
\hline & Alloaromadendrene & & 3.2 & & & & & \\
\hline
\end{tabular}

* MIR denotes maximum incremental reactivity ( $\mathrm{g} \mathrm{O}_{3} / \mathrm{g} \mathrm{VOCs}$ ) (Carter, 2009). The rate constants are from Atkinson (2000) and Atkinson and Arey (2003b) except those for $\alpha$-humulene and longifolene OH reaction rates, which are from Shu and Atkinson (1995). Other sesquiterpene data are from CSID:1406720, http://www.chemspider.com/Chemical-Structure.1406720.html (last access: 2 May 2016). Predicted data are generated using the US Environmental Protection Agency's EPI Suite.

a function of the number of independent variables included in the optimum MLR solution, is presented. It is evident that interdependence between temperature, soil temperatures and PAR yielded the largest decrease in RMSE for isoprene concentrations measured. However, for MBO, monoterpene and SQT, a much more significant contribution from soil moisture is observed to decrease the RMSE differences between calculated and measured BVOC levels. It is also evident that the interdependence between soil moisture and soil temperature at $20 \mathrm{~cm}$ is important to estimate $\mathrm{MBO}$, monoterpene and SQT concentrations. Therefore, explorative MLR indicated that temperature had the largest influence on isoprene concentrations, while soil moisture was the most significant for MBO, monoterpene and SQT levels.

\subsection{Reactivity of BVOCs}

It is important to evaluate the significance of BVOCs on their atmospheric reactivity, since these species are important precursor species in the photochemical formation of tropospheric $\mathrm{O}_{3}$ and SOA. This is particularly relevant for South Africa, with various recent studies indicating that $\mathrm{O}_{3}$ is currently the most problematic pollutant in South Africa (Laakso et al., 2013; Venter et al., 2012; Beukes et al., 2013). In addition, Vakkari et al. (2015) also indicated the importance of VOCs for new particle formation and growth. There- fore, the $\mathrm{O}_{3}$ formation potential (OFP), reaction rates with $\mathrm{O}_{3}$ and $\mathrm{OH}$ reactivities of the BVOCs measured in this study were evaluated.

The OFP of BVOCs was determined by calculating the product of the average concentration and the maximum incremental reactivity (MIR) coefficient of each compound, i.e. OFP $=$ VOC $\times$ MIR (Carter, 2009). The MIR scale has been used to assess OFP for aromatic hydrocarbons in numerous previous studies (Hoque et al., 2008; Jaars et al., 2014; Na et al., 2005). The reaction rates for reactions between $\mathrm{O}_{3}$ and BVOCs were calculated with Eq. (3):

reaction rates $=k_{X, \mathrm{O}_{3}}[X]\left[\mathrm{O}_{3}\right]$,

where $[X]$ is the BVOC concentration, $\left[\mathrm{O}_{3}\right]$ the ozone concentration and $k_{X, \mathrm{O}_{3}}$ the reaction rate constant for the reaction between $X$ and $\mathrm{O}_{3}$. Since direct $\mathrm{OH}$ reactivity measurements were not available, the $\mathrm{OH}$ reactivities $\left(\mathrm{s}^{-1}\right)$ of the BVOCs were calculated, using Eq. (4):

$\mathrm{OH}$ reactivity $=k_{X, \mathrm{OH}}[X]$,

where $[X]$ is the $\mathrm{BVOC}$ concentration and $k_{X, \mathrm{OH}}$ the reaction rate constant of the reaction between $\mathrm{X}$ and $\mathrm{OH}$. In Table 5, the OFP calculated for each of the BVOCs measured in this study, as well as the reaction rate constants for the reactions of these species with $\mathrm{O}_{3}$ and $\mathrm{OH}$, are listed. 



Figure 8. (a) Monthly means of reaction rates calculated for reactions between $\mathrm{O}_{3}$ and BVOCs at Welgegund. A secondary axis is introduced for reaction rates calculated for February 2015 due to much higher reaction rates calculated for this month. (b) The relative monthly contribution of different BVOCs to the $\mathrm{OH}$ reactivity at Welgegund.

Table 5 indicates that, according to the OFP calculated with MIR coefficients, $\alpha$-pinene, isoprene and p-cymene had the highest OFP in descending order during the first sampling campaign. During the second sampling campaign, $\alpha$ pinene also had the highest OFP, while limonene and isoprene had the second and third highest OFPs, respectively. A comparison of the OFP calculated in this study to the OFP calculated by Jaars et al. (2014) for anthropogenic aromatic hydrocarbons measured at Welgegund (with MIR coefficients) indicates that the OFP of BVOCs is an order of magnitude smaller than the OFP of aromatic hydrocarbons at Welgegund. The combined $\mathrm{O}_{3}$ formation potentials of all the BVOCs measured calculated with MIR coefficients during the first and second campaign were 1162 and 1022 pptv, respectively.
In Fig. 8a, the monthly mean reaction rates for the reactions between $\mathrm{O}_{3}$ and BVOCs measured in this study are presented. Higher reaction rates between $\mathrm{BVOCs}$ and $\mathrm{O}_{3}$ contribute to increased atmospheric $\mathrm{O}_{3}$ depletion. Significantly higher reaction rates were calculated for February 2015. It is evident from Fig. 8a that $\alpha$-pinene and limonene had the highest reaction rates with $\mathrm{O}_{3}$, while isoprene exhibited relatively small contributions the $\mathrm{O}_{3}$ depletion. The other BVOCs also had relatively low reaction rates for their reactions with $\mathrm{O}_{3}$. In Fig. 8b, the relative monthly contributions of each of the BVOCs to the total $\mathrm{OH}$ reactivity of BVOCs are presented. It is evident that largest contributions to the $\mathrm{OH}$ reactivity of BVOCs measured at Welgegund are from limonene, $\alpha$-pinene and terpinolene for all of the months during both sampling campaigns. This is expected, since monoterpenes had the highest atmospheric concentra- 
tions compared to the other BVOCs measured in this study. It is also evident, especially during the first sampling campaign, that isoprene levels increased with the onset of spring in September.

\section{Conclusions}

The annual median concentrations of isoprene, MBO, monoterpene and SQT determined during two sampling campaigns indicated that the sum of the concentrations of the monoterpenes was an order of magnitude higher than the concentrations of other BVOC species, with $\alpha$-pinene being the most abundant species. Although monoterpene concentrations were similar to levels measured at other regions in the world and in a South Africa, very low isoprene concentrations at Welgegund led to a significantly lower total BVOC concentration compared to levels reported in most previous studies. In addition, total BVOC concentrations were an order of magnitude lower compared to the total aromatic VOC concentrations measured by Jaars et al. (2014) at Welgegund.

Distinct seasonal patterns were observed for MBO during both sampling campaigns, which coincided with wet and warmer months. Although less pronounced, a similar seasonal trend than for MBO was observed for isoprene during the first sampling campaign, while higher isoprene concentrations during the second sampling campaign were associated with higher wind speeds that indicated a distant source region of isoprene. No distinct seasonal pattern was observed for monoterpene and SQT concentrations. However, significantly higher levels of monoterpene and SQT, as well as MBO were measured from February to April 2011 during the first sampling campaign, which were attributed to the considerably higher soil moisture measured at a depth of $20 \mathrm{~cm}$ resulting for the wet season preceding the first campaign and is indicative of biogenic emissions from deep-rooted plants.

Woody species in the grassland region were considered to be the main sources of BVOCs measured, while sunflower and maize crops were also considered to be potential sources for BVOCs in this region. Multilinear regression analysis indicated that soil moisture had the most significant impact on atmospheric levels of MBO, monoterpene and SQT concentrations, while temperature had the greatest influence on isoprene levels.

The $\mathrm{O}_{3}$ formation potentials of the BVOCs measured were an order of magnitude smaller than that determined for anthropogenic VOCs measured at Welgegund. Isoprene and the monoterpenes: $\alpha$-pinene, $\mathrm{p}$-cymene, limonene and terpinolene, had the largest contribution to $\mathrm{O}_{3}$ formation potential. $\alpha$-Pinene and limonene had the highest reaction rates with $\mathrm{O}_{3}$, while isoprene exhibited relatively small contributions to the $\mathrm{O}_{3}$ depletion. Limonene, $\alpha$-pinene and terpinolene had the largest contributions to the OH-reactivity of BVOCs.

It is important in future work that a comprehensive study on BVOC emissions from specific plant species in the area surrounding Welgegund must be performed in order to relate the emission capacities of vegetation types to the atmospheric BVOCs measured. It is also recommended that the oxidation products of BVOC species are measured in order to verify distant source regions of BVOCs measured at Welgegund. In addition, the interactions between anthropogenic and biogenic VOCs must also be further explored, together with other ancillary measurements conducted at Welgegund (e.g. $\mathrm{SO}_{2}, \mathrm{NO}_{2}$ and $\mathrm{O}_{3}$ ). Future work must also include investigating the reactions of the measured VOCs with atmospheric oxidants (e.g. $\cdot \mathrm{OH}$ and $\mathrm{O}_{3}$ ) with atmospheric chemistry models in order to establish, for instance, whether $\mathrm{O}_{3}$ formation within the region is $\mathrm{VOC}$ or $\mathrm{NO}_{2}$ limited.

\section{Data availability}

The data of this paper are available upon request to Pieter van Zyl (pieter.vanzyl@nwu.ac.za) or Paul Beukes (paul.beukes@nwu.ac.za).

\section{The Supplement related to this article is available online at doi:10.5194/acp-16-15665-2016-supplement.}

Acknowledgements. The authors would like to acknowledge the Finnish Academy (project no. 132640), the University of Helsinki, the Finnish Meteorological Institute, the North-West University and the National Research Foundation (NRF) for financial support. Opinions expressed and conclusions arrived at are those of the authors and are not necessarily to be attributed to the NRF. Assistance with data processing from Rosa Gierens is also acknowledged.

Edited by: S. E. Pusede

Reviewed by: two anonymous referees

\section{References}

Andreae, M. O. and Crutzen, P. J.: Atmospheric aerosols: Biogeochemical sources and role in atmospheric chemistry, Science, 276, 1052-1058, 1997.

Atkinson, R.: Atmospheric chemistry of VOCs and $\mathrm{NO}_{x}$, Atmos. Environ., 34, 2063-2101, 2000.

Atkinson, R. and Arey, J.: Gas-phase tropospheric chemistry of biogenic volatile organic compounds: a review, Atmos. Environ., 37, 197-219, doi:10.1016/s1352-2310(03)00391-1, 2003a.

Atkinson, R. and Arey, J.: Atmospheric degradation of volatile organic compounds, Chem. Rev., 103, 4605-4638, 2003b.

Bamberger, I., Hörtnagl, L., Ruuskanen, T., Schnitzhofer, R., Müller, M., Graus, M., Karl, T., Wohlfahrt, G., and Hansel, A.: Deposition fluxes of terpenes over grassland, J. Geophys. Res.Atmos., 116, D14305, doi:10.1029/2010JD015457, 2011. 
Beukes, J. P., Vakkari, V., Van Zyl, P. G., Venter, A. D., Josipovic, M., Jaars, K., Tiitta, P., Kulmala, M., Worsnop, D., and Pienaar, J. J.: Source region plume characterization of the interior of South Africa, as observed at Welgegund, National Association for Clean Air, The Clean Air Journal, 23, 7-10, 2013.

Beukes, J. P., Venter, A. D., Josipovic, M., Van Zyl, P. G., Vakkari, V., Jaars, K., Dunn, M., and Laakso, L.: Automated Continuous Air Monitoring, Comprehensive Analytical Chemistry, 70, 183208, 2015.

Blande, J. D., Holopainen, J. K., and Niinemets, Ü.: Plant volatiles in polluted atmospheres: stress responses and signal degradation, Plant Cell Environ., 37, 1892-1904, 2014.

Bond, W. J.: Ancient grasslands at risk, Science, 351, 120-122, 2016.

Bouvier-Brown, N. C., Goldstein, A. H., Worton, D. R., Matross, D. M., Gilman, J. B., Kuster, W. C., Welsh-Bon, D., Warneke, C., de Gouw, J. A., Cahill, T. M., and Holzinger, R.: Methyl chavicol: characterization of its biogenic emission rate, abundance, and oxidation products in the atmosphere, Atmos. Chem. Phys., 9, 2061-2074, doi:10.5194/acp-9-2061-2009, 2009.

Carter, W. P.: Updated maximum incremental reactivity scale and hydrocarbon bin reactivities for regulatory applications, California Air Resources Board Contract, 07-339, 2009.

Chang, C.-C., Wang, J.-L., Candice Lung, S.-C., Chang, C.-Y., Lee, P.-J., Chew, C., Liao, W.-C., Chen, W.-N., and Ou-Yang, C.-F.: Seasonal characteristics of biogenic and anthropogenic isoprene in tropical-subtropical urban environments, Atmos. Environ., 99, 298-308, doi:10.1016/j.atmosenv.2014.09.019, 2014.

Ciccioli, P., Centritto, M., and Loreto, F.: Biogenic volatile organic compound emissions from vegetation fires, Plant Cell Environ., 37, 1810-1825, 2014.

Conradie, E. H., van Zyl, P. G., Pienaar, J. J., Beukes, J. P., Galy-Lacaux, C., Venter, A. D., and Mkhatshwa, G. V.: Assessment of precipitation chemistry and wet deposition in the interior of South Africa, Atmos. Environ., 146, 113-131, doi:10.1016/j.atmosenv.2016.07.033, 2016.

Daemane, M. E., Cilliers, S. S., and Bezuidenhout, H.: An ecological study of the plant communities in the proposed Highveld National Park, in the peri-urban area of Potchefstroom, South Africa, Koedoe, 52, doi:10.4102/koedoe.v52i1.708, 2010.

Davison, B., Taipale, R., Langford, B., Misztal, P., Fares, S., Matteucci, G., Loreto, F., Cape, J. N., Rinne, J., and Hewitt, C. $\mathrm{N}$.: Concentrations and fluxes of biogenic volatile organic compounds above a Mediterranean macchia ecosystem in western Italy, Biogeosciences, 6, 1655-1670, doi:10.5194/bg-6-16552009, 2009.

Di Carlo, P., Brune, W. H., Martinez, M., Harder, H., Lesher, R., Ren, X., Thornberry, T., Carroll, M. A., Young, V., and Shepson, P. B.: Missing OH reactivity in a forest: Evidence for unknown reactive biogenic VOCs, Science, 304, 722-725, 2004.

Eerdekens, G., Yassaa, N., Sinha, V., Aalto, P. P., Aufmhoff, H., Arnold, F., Fiedler, V., Kulmala, M., and Williams, J.: VOC measurements within a boreal forest during spring 2005: on the occurrence of elevated monoterpene concentrations during night time intense particle concentration events, Atmos. Chem. Phys., 9, 8331-8350, doi:10.5194/acp-9-8331-2009, 2009.

Ehn, M., Thornton, J. A., Kleist, E., Sipilä, M., Junninen, H., Pullinen, I., Springer, M., Rubach, F., Tillmann, R., and Lee, B.: A large source of low-volatility secondary organic aerosol, Nature, 506, 476-479, 2014.

Fuentes, J. D., Gu, L., Lerdau, M., Atkinson, R., Baldocchi, D., Bottenheim, J., Ciccioli, P., Lamb, B., Geron, C., and Guenther, A.: Biogenic hydrocarbons in the atmospheric boundary layer: a review, B. Am. Meteorol. Soc., 81, 1537-1575, 2000.

Fuentes, J. D., Wang, D., Bowling, D. R., Potosnak, M., Monson, R. K., Goliff, W. S., and Stockwell, W. R.: Biogenic hydrocarbon chemistry within and above a mixed deciduous forest, J. Atmos. Chem., 56, 165-185, 2007.

Gouinguené, S. P. and Turlings, T. C.: The effects of abiotic factors on induced volatile emissions in corn plants, Plant Physiol., 129, 1296-1307, 2002.

Grant, D. D., Fuentes, J. D., Chan, S., Stockwell, W. R., Wang, D., and Ndiaye, S. A.: Volatile organic compounds at a rural site in western Senegal, J. Atmos. Chem., 60, 19-35, 2008.

Gray, D. W., Breneman, S. R., Topper, L. A., and Sharkey, T. D.: Biochemical characterization and homology modeling of methylbutenol synthase and implications for understanding hemiterpene synthase evolution in plants, J. Biol. Chem., 286, 20582-20590, doi:10.1074/jbc.M111.237438, 2011.

Greenberg, J., Guenther, A., Harley, P., Otter, L., Veenendaal, E., Hewitt, C., James, A., and Owen, S.: Eddy flux and leaflevel measurements of biogenic VOC emissions from mopane woodland of Botswana, J. Geophys. Res.-Atmos., 108, 8466, doi:10.1029/2002JD002317, 2003.

Greenberg, J. P., Guenther, A., Zimmerman, P., Baugh, W., Geron, C., Davis, K., Helmig, D., and Klinger, L. F.: Tethered balloon measurements of biogenic VOCs in the atmospheric boundary layer, Atmos. Environ., 33, 855-867, 1999.

Guenther, A.: Biological and Chemical Diversity of Biogenic Volatile Organic Emissions into the Atmosphere, ISRN Atmospheric Sciences, 2013, 1-27, doi:10.1155/2013/786290, 2013.

Guenther, A. B., Jiang, X., Heald, C. L., Sakulyanontvittaya, T., Duhl, T., Emmons, L. K., and Wang, X.: The Model of Emissions of Gases and Aerosols from Nature version 2.1 (MEGAN2.1): an extended and updated framework for modeling biogenic emissions, Geosci. Model Dev., 5, 1471-1492, doi:10.5194/gmd-51471-2012, 2012.

Hakola, H., Laurila, T., Rinne, J., and Puhto, K.: The ambient concentrations of biogenic hydrocarbons at a northern European, boreal site, Atmos. Environ., 34, 4971-4982, 2000.

Hakola, H., Hellén, H., Tarvainen, V., Bäck, J., Patokoski, J., and Rinne, J.: Annual variations of atmospheric VOC concentrations in a boreal forest, Boreal Environ. Res., 14, 722-730, 2009.

Hakola, H., Hellén, H., Hemmilä, M., Rinne, J., and Kulmala, M.: In situ measurements of volatile organic compounds in a boreal forest, Atmos. Chem. Phys., 12, 11665-11678, doi:10.5194/acp12-11665-2012, 2012.

Harley, P., Otter, L., Guenther, A., and Greenberg, J.: Micrometeorological and leaf-level measurements of isoprene emissions from a southern African savanna, J. Geophys. Res.-Atmos., 108, 8468, doi:10.1029/2002JD002592, 2003.

Harrison, D., Hunter, M., Lewis, A., Seakins, P., Bonsang, B., Gros, V., Kanakidou, M., Touaty, M., Kavouras, I., and Mihalopoulos, N.: Ambient isoprene and monoterpene concentrations in a Greek fir (Abies Borisii-regis) forest. Reconciliation with emissions measurements and effects on measured $\mathrm{OH}$ concentrations, Atmos. Environ., 35, 4699-4711, 2001. 
Hellén, H., Kuronen, P., and Hakola, H.: Heated stainless steel tube for ozone removal in the ambient air measurements of mono- and sesquiterpenes, Atmos. Environ., 57, 35-40, doi:10.1016/j.atmosenv.2012.04.019, 2012a.

Hellén, H., Tykkä, T., and Hakola, H.: Importance of monoterpenes and isoprene in urban air in northern Europe, Atmos. Environ., 59, 59-66, 2012b.

Holopainen, J. K. and Gershenzon, J.: Multiple stress factors and the emission of plant VOCs, Trends Plant Sci., 15, 176-184, 2010.

Hoque, R. R., Khillare, P. S., Agarwal, T., Shridhar, V., and Balachandran, S.: Spatial and temporal variation of BTEX in the urban atmosphere of Delhi, India, Sci. Total Environ., 392, 30-40, doi:10.1016/j.scitotenv.2007.08.036, 2008.

Jaars, K., Beukes, J. P., van Zyl, P. G., Venter, A. D., Josipovic, M., Pienaar, J. J., Vakkari, V., Aaltonen, H., Laakso, H., Kulmala, M., Tiitta, P., Guenther, A., Hellén, H., Laakso, L., and Hakola, H.: Ambient aromatic hydrocarbon measurements at Welgegund, South Africa, Atmos. Chem. Phys., 14, 7075-7089, doi:10.5194/acp-14-7075-2014, 2014.

Jaoui, M., Kleindienst, T. E., Offenberg, J. H., Lewandowski, M., and Lonneman, W. A.: SOA formation from the atmospheric oxidation of 2-methyl-3-buten-2-ol and its implications for $\mathrm{PM}_{2.5}$, Atmos. Chem. Phys., 12, 2173-2188, doi:10.5194/acp-12-21732012, 2012.

Kesselmeier, J. and Staudt, M.: Biogenic volatile organic compounds (VOC): An overview on emission, physiology and ecology, J. Atmos. Chem., 33, 23-88, doi:10.1023/a:1006127516791, 1999.

Kesselmeier, J., Ciccioli, P., Kuhn, U., Stefani, P., Biesenthal, T., Rottenberger, S., Wolf, A., Vitullo, M., Valentini, R., and Nobre, A.: Volatile organic compound emissions in relation to plant carbon fixation and the terrestrial carbon budget, Global Biogeochem. Cy., 16, 1126, doi:10.1029/2001GB001813, 2002.

Kuhn, U., Rottenberger, S., Biesenthal, T., Wolf, A., Schebeske, G., Ciccioli, P., Brancaleoni, E., Frattoni, M., Tavares, T., and Kesselmeier, J.: Isoprene and monoterpene emissions of Amazonian tree species during the wet season: Direct and indirect investigations on controlling environmental functions, J. Geophys. Res.-Atmos., 107, 8071, doi:10.1029/2001JD000978, 2002.

Kulmala, M., Vehkamäki, H., Petäjä, T., Dal Maso, M., Lauri, A., Kerminen, V.-M., Birmili, W., and McMurry, P. H.: Formation and growth rates of ultrafine atmospheric particles: a review of observations, J. Aerosol Sci., 35, 143-176, 2004.

Kulmala, M., Kontkanen, J., Junninen, H., Lehtipalo, K., Manninen, H. E., Nieminen, T., Petäjä, T., Sipilä, M., Schobesberger, S., and Rantala, P.: Direct observations of atmospheric aerosol nucleation, Science, 339, 943-946, 2013.

Laakso, L., Merikanto, J., Vakkari, V., Laakso, H., Kulmala, M., Molefe, M., Kgabi, N., Mabaso, D., Carslaw, K. S., Spracklen, D. V., Lee, L. A., Reddington, C. L., and Kerminen, V.-M.: Boundary layer nucleation as a source of new $\mathrm{CCN}$ in savannah environment, Atmos. Chem. Phys., 13, 1957-1972, doi:10.5194/acp13-1957-2013, 2013.

Laothawornkitkul, J., Taylor, J. E., Paul, N. D., and Hewitt, C. N.: Biogenic volatile organic compounds in the Earth system, New Phytol., 183, 27-51, doi:10.1111/j.1469-8137.2009.02859.x, 2009.

Lappalainen, H. K., Sevanto, S., Bäck, J., Ruuskanen, T. M., Kolari, P., Taipale, R., Rinne, J., Kulmala, M., and Hari, P.: Day- time concentrations of biogenic volatile organic compounds in a boreal forest canopy and their relation to environmental and biological factors, Atmos. Chem. Phys., 9, 5447-5459, doi:10.5194/acp-9-5447-2009, 2009.

Lelieveld, J., Butler, T. M., Crowley, J. N., Dillon, T. J., Fischer, H., Ganzeveld, L., Harder, H., Lawrence, M. G., Martinez, M., Taraborrelli, D., and Williams, J.: Atmospheric oxidation capacity sustained by a tropical forest, Nature, 452, 737-740, doi:10.1038/nature06870, 2008.

Loreto, F. and Schnitzler, J.-P.: Abiotic stresses and induced BVOCs, Trends Plant Sci., 15, 154-166, 2010.

Lubbe, C. S., Siebert, S. J., and Cilliers, S. S.: Political legacy of South Africa affects the plant diversity patterns of urban domestic gardens along a socio-economic gradient, Sci. Res. Essays, 5, 290-291, 2010.

Lubbe, C. S., Siebert, S. J., and Cilliers, S. S.: A floristic analysis of domestic gardens in the Tlokwe Municipal area, South Africa, Bothalia, 41, 351-361, 2011.

Malhi, Y.: Carbon in the atmosphere and terrestrial biosphere in the 21st century, Philos. T. R. Soc. A, 360, 2925-2945, 2002.

Mauldin III, R., Berndt, T., Sipilä, M., Paasonen, P., Petäjä, T., Kim, S., Kurten, T., Stratmann, F., Kerminen, V.-M., and Kulmala, M.: A new atmospherically relevant oxidant of sulphur dioxide, Nature, 488, 193-196, 2012.

Mielke, L. H., Pratt, K. A., Shepson, P. B., McLuckey, S. A., Wisthaler, A., and Hansel, A.: Quantitative Determination of Biogenic Volatile Organic Compounds in the Atmosphere Using Proton-Transfer Reaction Linear Ion Trap Mass Spectrometry, Anal. Chem., 82, 7952-7957, 2010.

Misztal, P. K., Owen, S. M., Guenther, A. B., Rasmussen, R., Geron, C., Harley, P., Phillips, G. J., Ryan, A., Edwards, D. P., Hewitt, C. N., Nemitz, E., Siong, J., Heal, M. R., and Cape, J. N.: Large estragole fluxes from oil palms in Borneo, Atmos. Chem. Phys., 10, 4343-4358, doi:10.5194/acp-10-4343-2010, 2010.

Mucina, L. and Rutherford, M. C.: The Vegetation of South Africa, Lesotho and Swaziland, South African National Biodiversity Institute, 2006.

Na, K., Moon, K.-C., and Kim, Y. P.: Source contribution to aromatic VOC concentration and ozone formation potential in the atmosphere of Seoul, Atmos. Environ., 39, 5517-5524, 2005.

Nakashima, Y., Kato, S., Greenberg, J., Harley, P., Karl, T., Turnipseed, A., Apel, E., Guenther, A., Smith, J., and Kajii, Y.: Total $\mathrm{OH}$ reactivity measurements in ambient air in a southern Rocky mountain ponderosa pine forest during BEACHONSRM08 summer campaign, Atmos. Environ., 85, 1-8, 2014.

Noe, S. M., Hüve, K., Niinemets, Ü., and Copolovici, L.: Seasonal variation in vertical volatile compounds air concentrations within a remote hemiboreal mixed forest, Atmos. Chem. Phys., 12, 3909-3926, doi:10.5194/acp-12-3909-2012, 2012.

Otter, L., Guenther, A., and Greenberg, J.: Seasonal and spatial variations in biogenic hydrocarbon emissions from southern African savannas and woodlands, Atmos. Environ., 36, 4265-4275, 2002.

Otter, L., Guenther, A., Wiedinmyer, C., Fleming, G., Harley, P., and Greenberg, J.: Spatial and temporal variations in biogenic volatile organic compound emissions for Africa south of the equator, J. Geophys. Res.-Atmos., 108, 8505, doi:10.1029/2002JD002609, 2003.

Peñuelas, J. and Llusià, J.: BVOCs: plant defense against climate warming?, Trends Plant Sci., 8, 105-109, 2003. 
Peñuelas, J. and Staudt, M.: BVOCs and global change, Trends Plant Sci., 15, 133-144, 2010.

Räisänen, T., Ryyppö, A., and Kellomäki, S.: Monoterpene emission of a boreal Scots pine (Pinus sylvestris L.) forest, Agr. Forest Meteorol., 149, 808-819, 2009.

Rantala, P., Aalto, J., Taipale, R., Ruuskanen, T. M., and Rinne, J.: Annual cycle of volatile organic compound exchange between a boreal pine forest and the atmosphere, Biogeosciences, 12, 5753-5770, doi:10.5194/bg-12-5753-2015, 2015.

Räsänen, M., Aurela, M., Vakkari, V., Beukes, J. P., Van Zyl, P. G., Josipovic, M., Venter, A. D., Jaars, K., Siebert, S. J., Laurila, T., Tuovinen, J.-P., Rinne, J., and Laakso, L.: Carbon balance of a grazed savanna grassland ecosystem in South Africa, Biogeosciences Discuss., doi:10.5194/bg-2016-268, in review, 2016.

Rinne, H., Guenther, A., Greenberg, J., and Harley, P.: Isoprene and monoterpene fluxes measured above Amazonian rainforest and their dependence on light and temperature, Atmos. Environ., 36, 2421-2426, 2002.

Rinne, J., Hakola, H., Laurila, T., and Rannik, Ü.: Canopy scale monoterpene emissions of Pinus sylvestris dominated forests, Atmos. Environ., 34, 1099-1107, 2000.

Rinne, J., Ruuskanen, T. M., Reissell, A., Taipale, R., Hakola, H., and Kulmala, M.: On-line PTR-MS measurements of atmospheric concentrations of volatile organic compounds in a European boreal forest ecosystem, Boreal Environ. Res., 10, 425-436, 2005.

Rouget, M., Richardson, D. M., Nel, J. L., and Van Wilgen, B. W.: Commercially important trees as invasive aliens - towards spatially explicit risk assessment at a national scale, Biol. Invasions, 4, 397-412, 2002.

Ruuskanen, T. M., Müller, M., Schnitzhofer, R., Karl, T., Graus, M., Bamberger, I., Hörtnagl, L., Brilli, F., Wohlfahrt, G., and Hansel, A.: Eddy covariance VOC emission and deposition fluxes above grassland using PTR-TOF, Atmos. Chem. Phys., 11, 611-625, doi:10.5194/acp-11-611-2011, 2011.

Saxton, J. E., Lewis, A. C., Kettlewell, J. H., Ozel, M. Z., Gogus, F., Boni, Y., Korogone, S. O. U., and Serça, D.: Isoprene and monoterpene measurements in a secondary forest in northern Benin, Atmos. Chem. Phys., 7, 4095-4106, doi:10.5194/acp-74095-2007, 2007.

Schuh, G., Heiden, A., Hoffmann, T., Kahl, J., Rockel, P., Rudolph, J., and Wildt, J.: Emissions of volatile organic compounds from sunflower and beech: dependence on temperature and light intensity, J. Atmos. Chem., 27, 291-318, 1997.

Serca, D., Guenther, A., Klinger, L., Vierling, L., Harley, P., Druilhet, A., Greenberg, J., Baker, B., Baugh, W., and Bouka-Biona, C.: EXPRESSO flux measurements at upland and lowland Congo tropical forest site, Tellus B, 53, 220-234, 2001.

Sharkey, T. D. and Yeh, S.: Isoprene emission from plants, Ann. Rev. Plant Biol., 52, 407-436, 2001.

Shu, Y. and Atkinson, R.: Atmospheric lifetimes and fates of a series of sesquiterpenes, J. Geophys. Res.-Atmos., 100, 72757281, 1995.

Siebert, S. J.: Patterns of plant species richness of temperate and tropical grassland in South Africa, Plant Ecology and Evolution, 144, 249-254, 2011.
Spirig, C., Neftel, A., Ammann, C., Dommen, J., Grabmer, W., Thielmann, A., Schaub, A., Beauchamp, J., Wisthaler, A., and Hansel, A.: Eddy covariance flux measurements of biogenic VOCs during ECHO 2003 using proton transfer reaction mass spectrometry, Atmos. Chem. Phys., 5, 465-481, doi:10.5194/acp-5-465-2005, 2005.

Stroud, C., Makar, P., Karl, T., Guenther, A., Geron, C., Turnipseed, A., Nemitz, E., Baker, B., Potosnak, M., and Fuentes, J. D.: Role of canopy-scale photochemistry in modifying biogenicatmosphere exchange of reactive terpene species: Results from the CELTIC field study, J. Geophys. Res.-Atmos., 110, D17303, doi:10.1029/2005JD005775, 2005.

Tiitta, P., Vakkari, V., Croteau, P., Beukes, J. P., van Zyl, P. G., Josipovic, M., Venter, A. D., Jaars, K., Pienaar, J. J., Ng, N. L., Canagaratna, M. R., Jayne, J. T., Kerminen, V.-M., Kokkola, H., Kulmala, M., Laaksonen, A., Worsnop, D. R., and Laakso, L.: Chemical composition, main sources and temporal variability of $\mathrm{PM}_{1}$ aerosols in southern African grassland, Atmos. Chem. Phys., 14, 1909-1927, doi:10.5194/acp-14-1909-2014, 2014.

Tunved, P., Hansson, H.-C., Kerminen, V.-M., Ström, J., Dal Maso, M., Lihavainen, H., Viisanen, Y., Aalto, P., Komppula, M., and Kulmala, M.: High natural aerosol loading over boreal forests, Science, 312, 261-263, 2006.

Tyson, P., Garstang, M., and Swap, R.: Large-scale recirculation of air over southern Africa, J. Appl. Meteorol., 35, 2218-2236, 1996.

Vakkari, V., Tiitta, P., Jaars, K., Croteau, P., Beukes, J. P., Josipovic, M., Kerminen, V. M., Kulmala, M., Venter, A. D., and Zyl, P. G.: Reevaluating the contribution of sulfuric acid and the origin of organic compounds in atmospheric nanoparticle growth, Geophys. Res. Lett., 42, 10486-10493, doi:10.1002/2015GL066459, 2015.

Venter, A. D., Vakkari, V., Beukes, J. P., Van Zyl, P. G., Laakso, H., Mabaso, D., Tiitta, P., Josipovic, M., Kulmala, M., and Pienaar, J. J.: An air quality assessment in the industrialised western Bushveld Igneous Complex, South Africa, S. Afr. J. Sci., 108, 1-10, 2012.

Wang, H. J., Xia, J. Y., Mu, Y. J., Nie, L., Han, X. G., and Wan, S. Q.: BVOCs emission in a semi-arid grassland under climate warming and nitrogen deposition, Atmos. Chem. Phys., 12, 3809-3819, doi:10.5194/acp-12-3809-2012, 2012.

Welgegund measurement station: available at: http://www. welgegund.org/, last access: 27 May 2016.

Welz, O., Savee, J. D., Osborn, D. L., Vasu, S. S., Percival, C. J., Shallcross, D. E., and Taatjes, C. A.: Direct kinetic measurements of Criegee intermediate $(\mathrm{CH} 2 \mathrm{OO})$ formed by reaction of CH2I with $\mathrm{O}_{2}$, Science, 335, 204-207, 2012.

Zunckel, M., Chiloane, K., Sowden, M., and Otter, L.: Biogenic volatile organic compounds: The state of knowledge in southern Africa and the challenges for air quality management, S. Afr. J. Sci., 103, 107-112, 2007. 